\title{
A critical role of glutathione in determining apoptosis sensitivity and resistance in leukemia cells
}

\author{
C Friesen ${ }^{1}$, Kiess $^{1}$ and K-M Debatin ${ }^{\star, 1}$ \\ 1 University Children's Hospital, Prittwitzstr.43, D-89075 Ulm, Germany \\ * Corresponding author: Professor Dr K-M Debatin. Tel: + 49-731-50027700; \\ Fax: + 49-731-50026681; E-mail: klaus-michael.debatin@medizin.uni-ulm.de
}

Received 13.6.03; revised 05.11.03; accepted 10.2.04; published online 23.4.04 Edited by A Finazzi-Agro

\begin{abstract}
In chemosensitive leukemias and solid tumors, anticancer drugs have been shown to induce apoptosis. Deficiencies in the apoptotic pathways may lead to chemoresistance. Here we report that glutathione (GSH) plays a critical role in activation of apoptosis pathways by CD95 (APO-1/Fas) or anticancer drugs. Upon treatment with anticancer drugs or CD95 triggering, CD95-resistant or $\mathrm{Bcl}-\mathrm{x}_{\mathrm{L}}$ overexpressing CEM cells were deficient in activation of apoptosis pathways. CD95-resistant and BCl- $x_{L}$ overexpressing CEM cells exhibited higher intracellular GSH levels in comparison to parental cells. Downregulation of GSH by L-buthionine-( $S, R)$-sulfoxime (BSO), a specific inhibitor of glutathione synthesis, reversed deficiencies in activation of apoptosis pathways by anticancer drugs or CD95. Interestingly, downregulation of GSH by BSO increased CD95 DISC formation in type I cells. In hybrids of CD95-resistant cells with sensitive cells and hybrids of overexpressing Bcl- $x_{L}$ cells with sensitive cells, the phenotype of apoptosis resistance was dominant. Also, in these hybrids, downregulation of GSH reversed CD95- and chemoresistance. We conclude that dominant apoptosis resistance depends, at least in part, on intracellular GSH levels, which may affect apoptosis signaling at different compartments, for example, the death receptor or mitochondria.

Cell Death and Differentiation (2004) 11, S73-S85.

doi:10.1038/sj.cdd.4401431

Published online 23 April 2004
\end{abstract}

Keywords: glutathione; apoptosis resistance; CD95; anticancer drug; cell fusion

Abbreviations: AICD, activation-induced cell death; AIF, apoptosis-inducing factor; BSO, L-buthionine-( $S, R)$-sulfoxime; CD95L, CD95 ligand; CD95, CD95 receptor; DISC, death-inducing signaling complex; Doxo, doxorubicin; $\Delta \Psi \mathrm{m}$, mitochondrial membrane potential; FADD, Fas-associated death domain; FSC, forward scatter; GSH, glutathione; NGF, nerve growth factor; PARP, poly(ADP-ribose)polymerase; PFA, paraformaldehyde; PI, propidium iodide; PMSF, phenyl methyl sulfonyl fluoride; PT, permeability transition; ROS, reactive oxygen species; SSC, side scatter; TNF, tumor necrosis factor; XIAP, X-linked inhibitor-of-apoptosis protein

\section{Introduction}

A wide range of anticancer drugs, including chemotherapeutic agents, hormones, and various biologicals, induce apoptosis in malignant sensitive cells in vitro. ${ }^{1,2}$ Changes in the ability to activate the apoptotic machinery may play a role in drug resistance.

The CD95 cell surface receptor (CD95) is a member of the tumor necrosis factor/nerve growth factor (TNF/NGF) receptor superfamily of cell surface molecules which mediates apoptosis upon oligomerization. ${ }^{3-8}$ CD95 crosslinking by agonistic antibodies or the natural ligand initiates trimerization of CD95 and recruitment of adapter molecules Fas-associated death domain (FADD) and procaspase-8 to form the death-inducing signaling complex (DISC), that leads to activation of caspases, which play a crucial role in apoptosis. ${ }^{5}$ Apoptogenic caspases are divided into two classes, effector caspases and initiator caspases. Effector caspases are responsible for the cleavage that disassembles the cell, and initiator caspases initiate the proteolytic cascade. Caspase-3, -6 , and -7 are the effector caspases and caspase -8 and -9 are the major initiator caspases.

The CD95 ligand (CD95-L) is a member of the corresponding family of TNF-related cytokines, which is found in a soluble or membrane-bound form. CD95-L may cause autocrine suicide in sensitive $\mathrm{CD} 95^{+} \mathrm{T}$ cells and fratricide or paracrine death in neighboring T cells or other target cells. ${ }^{9-11}$ Although a controversial issue, a number of studies have shown that activation of death receptor/ligand system such as the CD95 system may contribute to drug-induced apoptosis and altered death receptor signaling may play a role in chemoresistance. ${ }^{12-25}$

In most cases, drug-mediated apoptosis was found to involve pertubations of mitochondrial functions. ${ }^{15,26-29}$ Mitochondria-directed apoptotic stimuli induce a variety of mitochondrial changes such as the production of reactive oxygen species (ROS) and loss of mitochondrial membrane potential $\left(\Delta \Psi_{\mathrm{m}}\right)$. Disruption of $\Delta \Psi_{\mathrm{m}}$ is mediated by opening of permeability transition (PT) pores, thereby releasing apoptogenic factors such as cytochrome $c$, apoptosis-inducing factor (AIF), caspase-2, and -9 from mitochondria into the cytosol triggering caspase-3 activation through formation of the cytochrome c/Apaf-1/caspase-9-containing apoptosome complex. ${ }^{30-35}$ Caspase- 9 activity can be inhibited by X-linked inhibitor-of-apoptosis protein (XIAP) by interacting with caspase- $-9{ }^{36,37}$ Mitochondria-related apoptosis is regulated by Bcl-2 family members, which are involved in the cellular response to a variety of apoptotic stimuli including chemotherapeutic agents. ${ }^{38}$ Anticancer drugs were found to induce Bax expression ${ }^{39}$ and overexpression of $\mathrm{BCl}-2$ or $\mathrm{BCl}-\mathrm{x}_{\mathrm{L}}$ has been shown to prevent apoptosis and to reduce pertubation of mitochondrial function and hyperproduction of ROS by different apoptosis inducing stimuli. ${ }^{40-42}$

Death receptor-induced apoptosis may depend in a cell type-specific manner on the mitochondrial pathway. In type I 
cells, for example H9, SKW6.4, apoptosis is mediated by activation of caspase-8 at the CD95 DISC in large amounts, resulting in direct processing of caspase-3, a step which is independent of mitochondrial activation and cannot be blocked by Bcl-2. Alternatively, the mitochondrial apoptosis pathway is the preferred route in cells with reduced CD95 DISC formation (type II cells; for example, CEM, Jurkat) and mitochondria may function as amplifier in type II cells, activating both caspase- 8 and $-3 .{ }^{43}$ In addition, signals originating from CD95 receptor may be linked to mitochondria by Bid, which assumes cytochrome-c-releasing activity upon cleavage by caspase- $8 .{ }^{44}$ After anticancer drug treatment, Bid was cleaved prior to mitochondrial alterations in type I cells providing a molecular link between caspase-8 activation and (secondary) mitochondrial pertubations, whereas in type II cells mitochondria act as an amplifier in caspase-8 activation and Bid was cleaved downstream of mitochondria. ${ }^{44,45}$

ROS play a critical role in apoptosis signaling. Reduced glutathione (GSH, a cystein-containing tripeptide), the most abundant intracellular thiol, acts as a major antioxidant by protecting against the damaging effects of free radicals and ROS and may protect cells from apoptotic cell death. ${ }^{46-49}$ GSH exists in all cells in nature and is the only available scavenger to hydrogen peroxide in mitochondria. Hydrogen peroxide is a precursor of hydroxyl radical through the participation of transition metals. ROS play a crucial role in apoptosis and the cellular redox state and mitochondriaderived ROS could modulate induction of CD95 ligand by anticancer drugs. ${ }^{15,50}$ Interestingly, caspase- 8 activation at the DISC and DISC formation was found to be modulated by intracellular GSH levels in some systems. ${ }^{51}$ Reduction of ROS by ROS scavenger was able to block apoptosis induced by TNF, anticancer drugs, $\gamma$-irradiation, and activationinduced cell death in T cells (AICD). ${ }^{52,53}$

In this study, we investigated the role of intracellular GSH in determining apoptosis sensitivity and resistance in CD95resistant cells, in $\mathrm{Bcl}-\mathrm{x}_{\mathrm{L}}$ overexpressing cells, and in hybrids of apoptosis-sensitive and -resistant cells.

\section{Results}

\section{Drug sensitivity of CD95-sensitive and -resistant cells}

Resistance of tumor cells towards anticancer drug treatment may result from failure to activate apoptosis pathways. ${ }^{12-15}$ Previously, we found that CD95-resistant CEM cells generated by continuous long-term culture in agonistic antibody (anti-APO-1/anti-CD95) displayed cross-resistance to several anticancer drugs such as doxorubicin, etoposide, cytarabine, cisplatin, methotrexate, thioguanine, cyclophosphamide or vincristine (data not shown). ${ }^{12-14}$ To see whether acquisition of cross-resistance to anticancer drugs parallels the development of CD95 resistance, we treated CEM cells by consecutive rounds of anti-CD95 treatment and compared those cells to long-term CD95-resistant cells $\left(\mathrm{CEM}^{\mathrm{CD95R}-\mathrm{L}}\right)$. We found that, concomitant with increased CD95 resistance, shortterm-treated CEM cells also gradually developed drug resistance (Figure 1a). In addition, caspase-3 and -9 activation, and XIAP and PARP cleavage were blocked (Figure 1b, c) and disruption of mitochondrial membrane potential (Figure 1d) was significantly reduced after doxorubicin or CD95 treatment in short- and long-term CD95-resistant cells in comparison to parental cell lines. All experiments with doxorubicin also included other anticancer drugs to role out a drug-specific phenomenon (data not shown). This demonstrates that acquisition of death receptor resistance in these CEM cells is associated with resistance to other deathinducing stimuli.

\section{Downregulation of GSH with BSO reversed resistance and deficient activation of apoptosis pathways by doxorubicin and CD95 in CD95- resistant cells and in overexpressing $\mathrm{Bcl}-\mathrm{x}_{\mathrm{L}}$ cells}

We and others have found that induction of CD95 ligand and apoptosis by doxorubicin is modulated by the redox state and intracellular levels of GSH in chemoresistant tumor cells. ${ }^{15,50}$. Therefore, we investigated whether apoptosis resistance and deficient activation of apoptosis pathways by CD95 or anticancer drugs in short- and long-term CD95-resistant cells were also influenced by intracellular GSH levels. In long- and short-term CD95-resistant cell lines, we found higher intracellular GSH levels in comparison to parental CEM cells (Figure 2a). Concomitant with development of CD95 resistance and cross-resistance to anticancer drugs, upregulation of GSH levels was found in comparison to parental cell lines (Figure 2a). Upregulation of intracellular GSH was most probably due to an increase in its synthesis, since downregulation of GSH by BSO (Figure 2a), a specific inhibitor of glutathione synthesis, could reverse doxorubicin and CD95 resistance at a high nontoxic dose of $\mathrm{BSO}$, sufficient to reduce GSH levels in these CD95-resistant cells (Figure 2a). We used doses of BSO, which lowered the GSH content to values nearly the same as measured in sensitive CEM cells (Figure 2a). If we used higher concentrations of BSO which further lowered the GSH content, the resistant cells died with BSO alone (data not shown). In addition, activation of caspase-3, PARP cleavage (Figure 2c), and cytochrome $c$ release from mitochondria (Figure $2 \mathrm{~d}, \mathrm{e}$ ) after doxorubicin or CD95 treatment in CD95-resistant cells were restored after pretreatment with BSO. Furthermore, overexpression of $\mathrm{BCl}-\mathrm{x}_{\mathrm{L}}$ prevents cells from doxorubicin- and CD95-induced apoptosis and loss of $\Delta \Psi_{\mathrm{m}}$ and ROS generation (data not shown). ${ }^{40}$ Surprisingly, pretreatment of $\mathrm{Bcl}-\mathrm{x}_{\mathrm{L}}$ overexpressing CEM cells $\left(\mathrm{CEM}^{\mathrm{BCl}-\mathrm{xL}}\right)$ with the highest nontoxic dose of $B S O$ also reversed defective doxorubicin-induced apoptosis (Figure 3a), defective activation of caspase-3 (Figure 3b), PARP cleavage (Figure $3 b$ ), and cytochrome $c$ release from mitochondria (Figure 3c, d). Similar to previously published data ${ }^{58}$ reduction in the intracellular level of $\mathrm{GSH}$ by BSO resulted in downregulated expression of $\mathrm{Bcl}-\mathrm{x}_{\mathrm{L}}$ protein in $C E M^{B c l-x L}$ cells (Figure $3 e$ ). These data demonstrate that intracellular GSH levels are critical for apoptosis resistance and defective activation of apoptosis pathways by doxorubicin or CD95 in CD95-resistant and in $\mathrm{Bcl}-\mathrm{x}_{\mathrm{L}}$ overexpressing cells. 
a

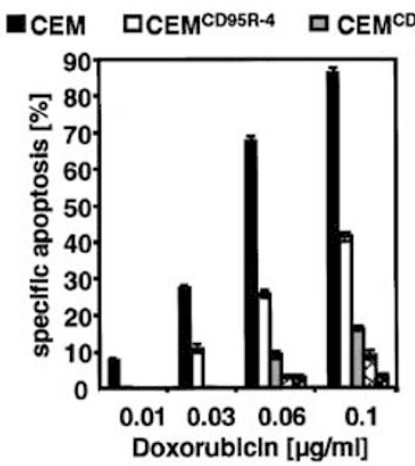

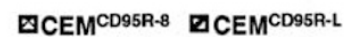

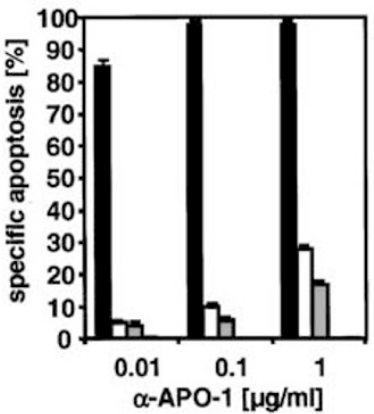

b
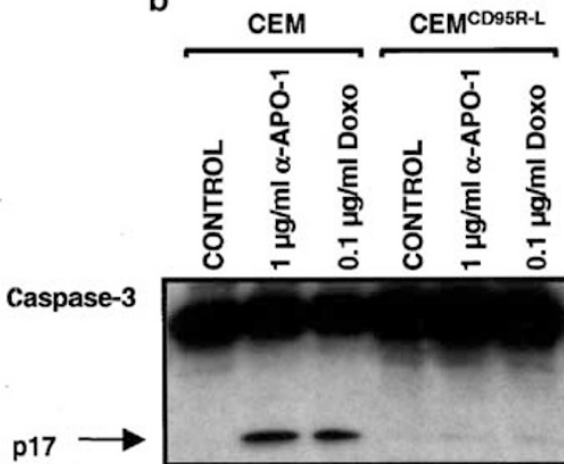

PARP

p116

p85

B-ActIn

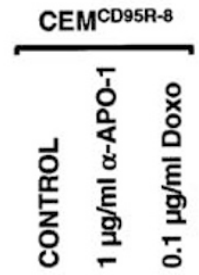

c

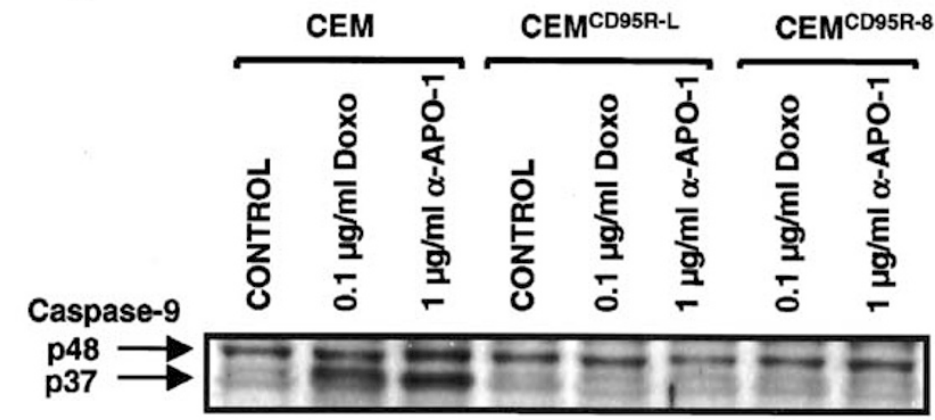

d
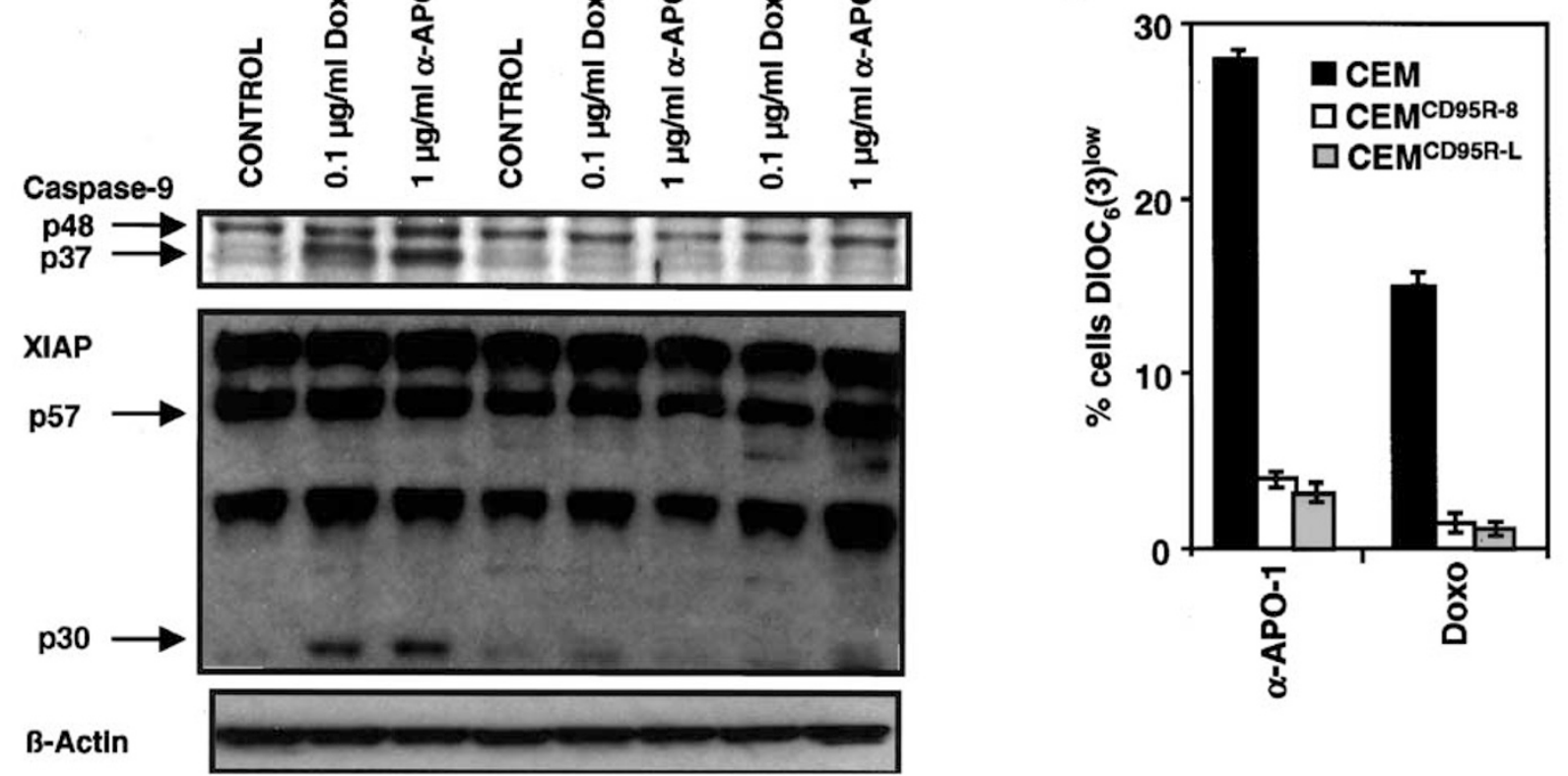

Figure 1 (a) Doxorubicin or CD95 induced apoptosis in CD95-sensitive and different generated CD95-resistant (CD95R) leukemia cells (CEM). CEM (black bars), $\mathrm{CEM}^{\mathrm{CD} 95 \mathrm{R}-4}$ (white bars), CEM ${ }^{\mathrm{CD} 95 \mathrm{R}-5}$ (gray bars), $\mathrm{CEM}^{\mathrm{CD} 95 \mathrm{R}-8}$ (gittered bars), and CEM ${ }^{\mathrm{CD} 95 \mathrm{R}-\mathrm{L}}$ (hatched bars) cells were incubated with different concentrations of doxorubicin or anti-APO-1 ( $\alpha$-APO-1) for $72 \mathrm{~h}$ as indicated. The percentage of apoptotic cells was measured by hypodiploid DNA. ${ }^{54}$ Percentage of specific cell death was calculated as follows: $100 \times$ (experimental dead cells $(\%)$-spontaneous dead cells in medium (\%)/100 \%-spontaneous dead cells in medium (\%)). Data are given as mean of triplicates with a standard deviation (S.D.) of less than $10 \%$. Similar results were obtained in three independent experiments. (b) Doxorubicin or CD95 induced

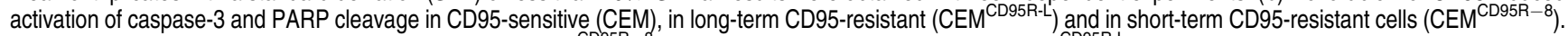
CD95-sensitive CEM, short-term CD95-resistant CEM (CEM ${ }^{\text {CD95R-8 }}$ ) and long-term CD95-resistant CEM (CEM ${ }^{\text {CD95R-L }}$ ) cells were incubated with doxorubicin (Doxo), anti-APO-1 $(\alpha$-APO-1) or left untreated (CONTROL) for $48 \mathrm{~h}$ at concentrations as indicated. Western blot analysis for caspase-3 and PARP was performed. The active fragment of caspase-3 was detected at $\sim 17 \mathrm{kDa}$ and the cleaved product of PARP at $\sim 85 \mathrm{kDa}$. Equal protein loading was controlled by beta-actin. (c) Doxorubicin or

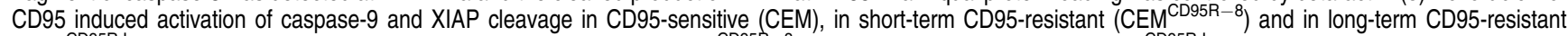
$\left(\mathrm{CEM}^{\mathrm{CD95R}-\mathrm{L}}\right.$ ) cells. CD95-sensitive (CEM), short-term CD95-resistant (CEM ${ }^{\mathrm{CD95R}-8}$ ), and long-term CD95-resistant (CEM ${ }^{\mathrm{CD} 95 \mathrm{R}-\mathrm{L}}$ ) cells were incubated with doxorubicin (Doxo), anti-APO-1 ( $\alpha$-APO-1) or left untreated (CONTROL) for $48 \mathrm{~h}$ at concentrations as indicated. Western blot analysis for caspase-9 and XIAP was performed. The active fragment of caspase- 9 was detected at $\sim 37 \mathrm{kDa}$ and the cleavage fragment of XIAP was detected at $\sim 30 \mathrm{kDa}$. Equal protein loading was controlled by betaactin. (d) Doxorubicin or CD95 induced downregulation of mitochondrial membrane potential $\left(\Delta \Psi_{\mathrm{m}}\right)$ in CD95-sensitive (CEM), in short-term CD95-resistant $\left(\mathrm{CEM}^{\mathrm{CD} 95 \mathrm{R}-8}\right)$ and in long-term CD95-resistant (CEM ${ }^{\mathrm{CD} 95 \mathrm{R}-\mathrm{L}}$ ) cells. CD95-sensitive (CEM, black bars), short-term CD95-resistant (CEM ${ }^{\mathrm{CD} 95 \mathrm{R}-8}$, white bars) and longterm CD95-resistant (CEM ${ }^{\mathrm{CD} 95 \mathrm{R}-\mathrm{L}}$, gray bars) leukemia cells were incubated with $1 \mu \mathrm{g} / \mathrm{ml}$ anti-APO-1 ( $\alpha$-APO-1), and $0.1 \mu \mathrm{g} / \mathrm{ml}$ doxorubicin (Doxo) at $37^{\circ} \mathrm{C}$. After $12 \mathrm{~h}$ frequency of cells with reduced $\Delta \Psi_{\mathrm{m}}\left[\mathrm{DiOC}_{6}(3)^{\mathrm{low}}\right]$ was measured. Data are given as mean of triplicates with an S.D. of less than $10 \%$. Similar results were obtained in three independent experiments 


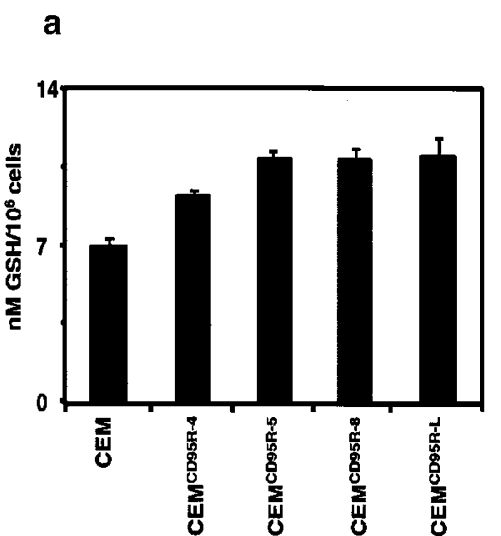

C

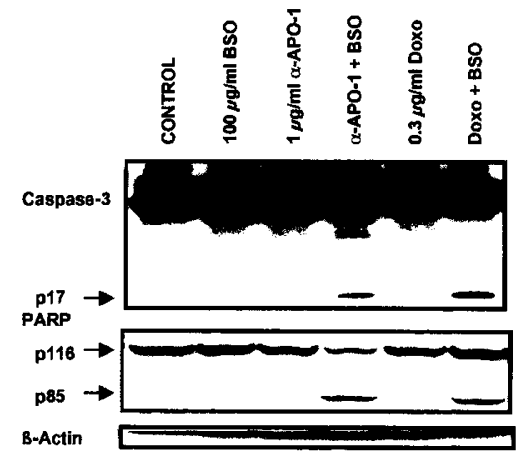

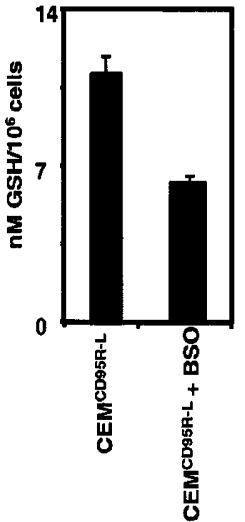

d
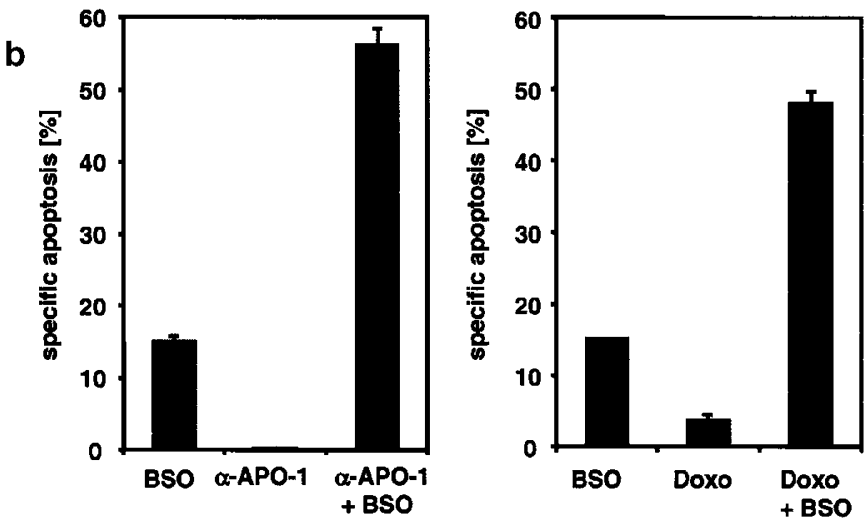

e
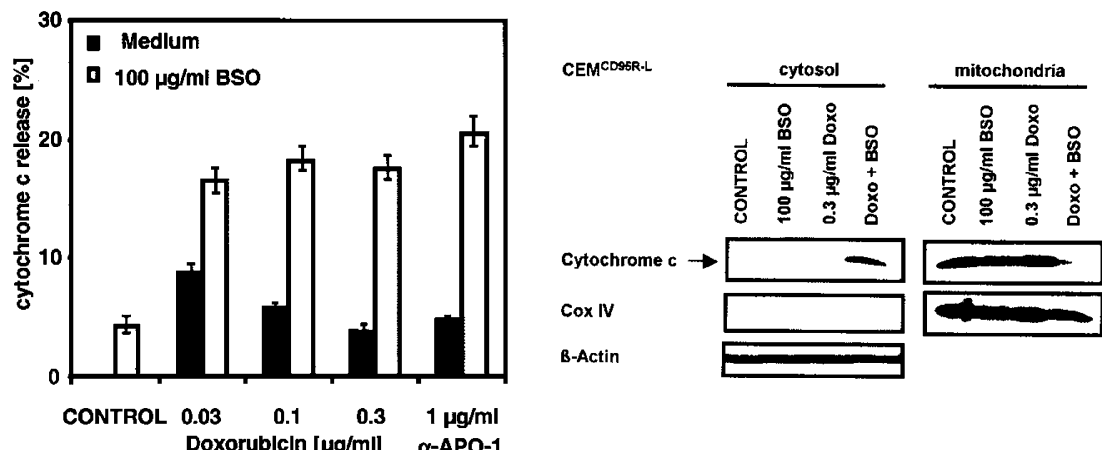

Figure 2 (a) Analysis of intracellular GSH content of chemosensitive parental (CEM) and CD95-resistant (CEM ${ }^{\text {CD95R-4 }}$ CEM $^{\text {CD95R-5}}$, CEM ${ }^{\text {CD95R-L }}$ ) cells and downregulation of intracellular GSH by BSO in CD95-resistant cells (CEM ${ }^{\text {CD95R-L }}$ ). Determination of intracellular GSH in chemosensitive parental (CEM) cells, CD95-

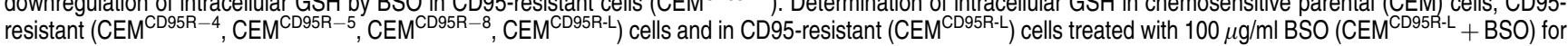
$24 \mathrm{~h}$. Data are given as mean of triplicates with an S.D. of less than $10 \%$. Similar results were obtained in three independent experiments. (b) Downregulation of

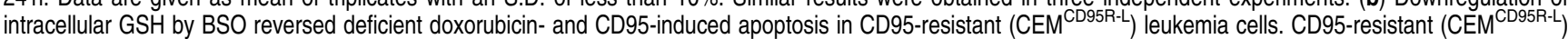
leukemia cells were incubated with $1 \mu \mathrm{g} / \mathrm{ml}$ anti-APO-1 ( $\alpha$-APO-1) or $0.03 \mu \mathrm{g} / \mathrm{ml}$ doxorubicin (Doxo) or preincubated for $12 \mathrm{~h}$ with $100 \mu \mathrm{g} / \mathrm{ml}$ BSO (BSO) by addition of anti-APO-1 ( $\alpha$-APO-1 + BSO) or doxorubicin (Doxo + BSO) at $37^{\circ} \mathrm{C}$. After $48 \mathrm{~h}$, the percentage of apoptotic cells was measured by FSC/SSC in leukemia cells. ${ }^{55}$ Data are given as mean of triplicates with an S.D. of less than $10 \%$. Similar results were obtained in three independent experiments. Percentage of specific cell death was calculated as described in Figure 1a. (c) Downregulation of intracellular GSH by BSO reversed deficient doxorubicin- and CD95-induced caspase-3 activation and PARP cleavage in CD95-resistant (CEM ${ }^{\text {CD95R-L) }}$ leukemia cells. CD95-resistant (CEM ${ }^{\mathrm{CD} 95 \mathrm{R}-\mathrm{L})}$ leukemia cells were incubated with $1 \mu \mathrm{g} / \mathrm{ml}$ anti-APO-1 $(\alpha-\mathrm{APO}-1)$ or $0.3 \mu \mathrm{g} / \mathrm{ml}$ doxorubicin (Doxo) or preincubated for $12 \mathrm{~h}$ with $100 \mu \mathrm{g} / \mathrm{ml} \mathrm{BSO}$ (BSO) by addition of anti-APO-1 ( $\alpha$-APO-1 + BSO) or preincubated for $12 \mathrm{~h} \mathrm{with} 100 \mu \mathrm{g} / \mathrm{ml}$ BSO (BSO) by addition of doxorubicin (Doxo + BSO) or left untreated (CONTROL) at $37^{\circ} \mathrm{C}$. Western blot analysis for caspase-3 and PARP was performed. The active fragment of caspase-3 was detected at $\sim 17 \mathrm{kDa}$ and the cleaved product of PARP at $\sim 85 \mathrm{kDa}$. Equal protein loading was controlled by beta-actin. (d, e) Downregulation of

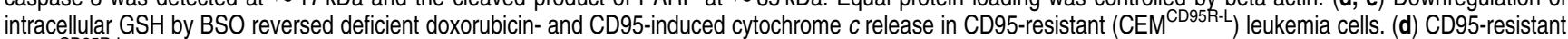
$\left(\mathrm{CEM}^{\mathrm{CD} 95 \mathrm{R}-\mathrm{L}}\right.$ ) leukemia cells were incubated with anti-APO-1 ( $\alpha$-APO-1, black bars) or doxorubicin (black bars) or preincubated for $12 \mathrm{~h}$ with $100 \mu \mathrm{g} / \mathrm{ml} \mathrm{BSO}$ (BSO) by addition of anti-APO-1 ( $\alpha$-APO-1, white bars) or preincubated for $12 \mathrm{~h}$ with $100 \mu \mathrm{g} / \mathrm{ml} \mathrm{BSO}$ (BSO) by addition of doxorubicin (white bars) at $37^{\circ} \mathrm{C}$ at concentrations as indicated. After $24 \mathrm{~h}$, cytochrome $\mathrm{c}$ release was performed by FACScan analysis. Data are given as mean of triplicates with an S.D. of less than $10 \%$. Similar results were obtained in three independent experiments. (e) CD95-resistant (CEM ${ }^{\mathrm{CD} 95 \mathrm{R}-\mathrm{L}}$ ) leukemia cells were incubated with $0.3 \mu \mathrm{g} / \mathrm{ml}$ doxorubicin (Doxo) or preincubated for $12 \mathrm{~h}$ with $100 \mu \mathrm{g} / \mathrm{ml} \mathrm{BSO}$ (BSO) by addition of doxorubicin (Doxo + BSO) or left untreated (CONTROL) at $37^{\circ} \mathrm{C}$. After $48 \mathrm{~h}$, cytochrome $c$ release was performed by Western Blot analysis of cytosolic and mitochondrial fraction. Equal protein loading was controlled for the cytosolic fraction using beta-actin and for the mitochondrial fraction using Cox IV

\section{Downregulation of GSH by BSO increases DISC formation depending on cell types}

Previously, DISC formation and activation of caspase-8 at the DISC was found to be modulated by intracellular GSH levels and ROS generation. ${ }^{51}$ The CD95 DISC contains several proteins including FADD and caspase- 8 containing several cystein residues, which could be modified by $\mathrm{GSH}^{51} \mathrm{We}$ therefore investigated if intracellular GSH levels could influence apoptosis signaling not only on mitochondria but also on DISC formation in our system (Figure 4a). CEM ${ }^{\mathrm{Neo}}$, $\mathrm{CEM}^{\mathrm{Bcl}-\mathrm{xL}}, \mathrm{CEM}^{\mathrm{CD} 95 \mathrm{R}-\mathrm{L}}$ cells (type II cells), and $\mathrm{H} 9$ cells (type I cells) serving as positive control for DISC formation were preincubated with or without a high nontoxic dose of BSO for $24 \mathrm{~h}$ in addition to CD95. CD95 DISC was immunoprecipitated and analyzed for CD95-associated proteins (Figure 4a) and 
a

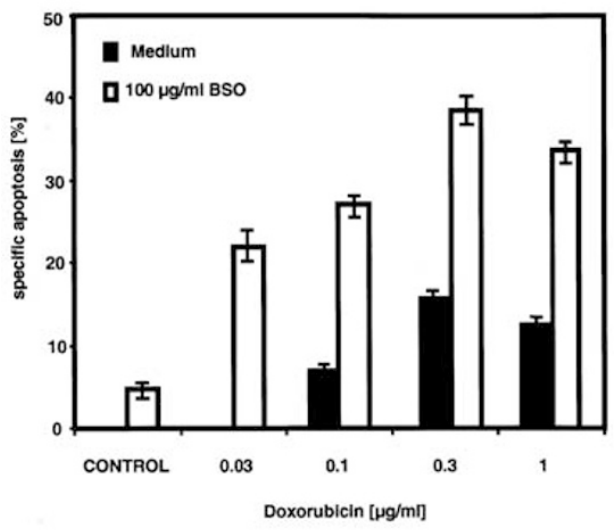

c

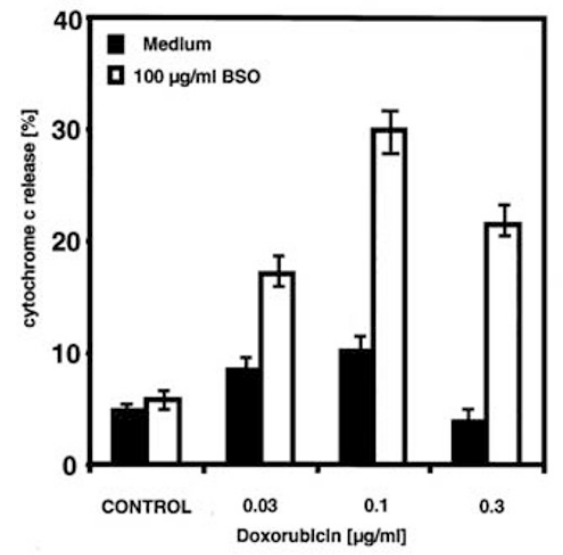

b

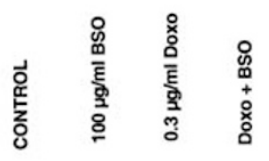

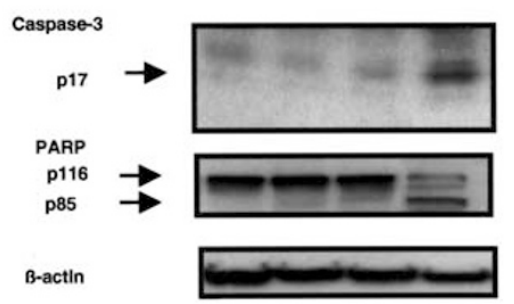

d

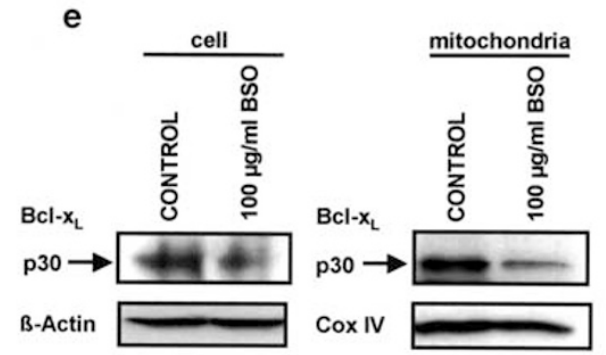

Figure 3 (a) BSO reversed deficient doxorubicin-induced apoptosis in Bcl-x $\mathrm{L}_{L}$ overexpressing leukemia cells $\left(\mathrm{CEM}^{\mathrm{BCl}-\mathrm{xL}}\right)$. CEM ${ }^{\mathrm{BCl}-\mathrm{xL}}$ were incubated with doxorubicin (black bars) or preincubated for $12 \mathrm{~h}$ with $100 \mu \mathrm{g} / \mathrm{ml} \mathrm{BSO}$ by addition of doxorubicin (white bars) at $37^{\circ} \mathrm{C}$ at concentrations as indicated. After $48 \mathrm{~h}$ the percentage of apoptotic cells was measured by FSC/SSC. ${ }^{55}$ Percentage of specific cell death was calculated as described in Figure 1a. Data are given as mean of triplicates with an S.D. of less than $10 \%$. Similar results were obtained in three independent experiments. (b) BSO reversed deficient doxorubicin-induced caspase-3 activation and PARP cleavage in $\mathrm{BCl}-\mathrm{x}_{\mathrm{L}}$ overexpressing leukemia cells $\left(\mathrm{CEM}^{\mathrm{BCl}-\mathrm{xL}}\right.$ ). $\mathrm{CEM}^{\mathrm{Bcl}-\mathrm{xL}}$ were incubated $0.3 \mu \mathrm{g} / \mathrm{ml}$ doxorubicin (Doxo) or left untreated (CONTROL) or preincubated for $12 \mathrm{~h}$ with $100 \mu \mathrm{g} / \mathrm{ml} \mathrm{BSO}$ (BSO) by addition of doxorubicin (Doxo + BSO) at $37^{\circ} \mathrm{C}$. After $72 \mathrm{~h}$ Western blot analysis for caspase-3 and PARP was performed. The active fragment of caspase- 3 was detected at $\sim 17 \mathrm{kDa}$ and the cleaved product of PARP at $\sim 85 \mathrm{kDa}$. Equal protein loading was controlled by beta-actin. (c, $\mathbf{d}) \mathrm{BSO}$ reversed deficient doxorubicin-induced cytochrome $c$ release in $B c l-x_{L}$ overexpressing leukemia cells $\left(C E M{ }^{B c l-x L}\right)$. (c) $C E^{B C l-x L}$ were incubated with doxorubicin (black bars) or preincubated for $12 \mathrm{~h}$ with $100 \mu \mathrm{g} / \mathrm{ml} \mathrm{BSO}$ by addition of doxorubicin (white bars) at $37^{\circ} \mathrm{C}$ at concentrations as indicated. After $24 \mathrm{~h}$, cytochrome $c$ release was performed by FASCcan analysis. Data are given as mean of triplicates with an S.D. of less than $10 \%$. Similar results were obtained in three independent experiments. (d) CEM ${ }^{B c 1-x L}$ were incubated with $0.3 \mu \mathrm{g} / \mathrm{ml}$ doxorubicin (Doxo) or preincubated for $12 \mathrm{~h}$ with $100 \mu \mathrm{g} / \mathrm{ml} \mathrm{BSO}$ (BSO) by addition of doxorubicin (Doxo + BSO) or left untreated (CONTROL) at $37^{\circ} \mathrm{C}$. After $48 \mathrm{~h}$, cytochrome $c$ release was performed by Western Blot analysis of cytosolic and mitochondrial fraction. Equal protein loading was controlled for the cytosolic fraction using beta-actin and for the mitochondrial fraction using Cox IV. (e) Downregulation of Bcl- $x_{\mathrm{L}}$ expression by BSO in Bcl- $\mathrm{x}_{\mathrm{L}}$ overexpressing leukemia cells (CEM ${ }^{B C l-x L}$ ). CEM $^{\text {Bcl-xL }}$ were incubated with $100 \mu \mathrm{g} / \mathrm{ml} \mathrm{BSO}$ or left untreated (CONTROL) at $37^{\circ} \mathrm{C}$. After $72 \mathrm{~h}$, Western blot analysis for Bcl$\mathrm{X}_{\mathrm{L}}$ of whole-cell population (cell) and mitochondrial fraction (mitochondria) was performed. Bcl- $\mathrm{X}_{\mathrm{L}}$ was detected at $\sim 30 \mathrm{kDa}$. Equal protein loading was controlled for the whole-cell population using beta-actin and for the mitochondrial fraction using Cox IV 


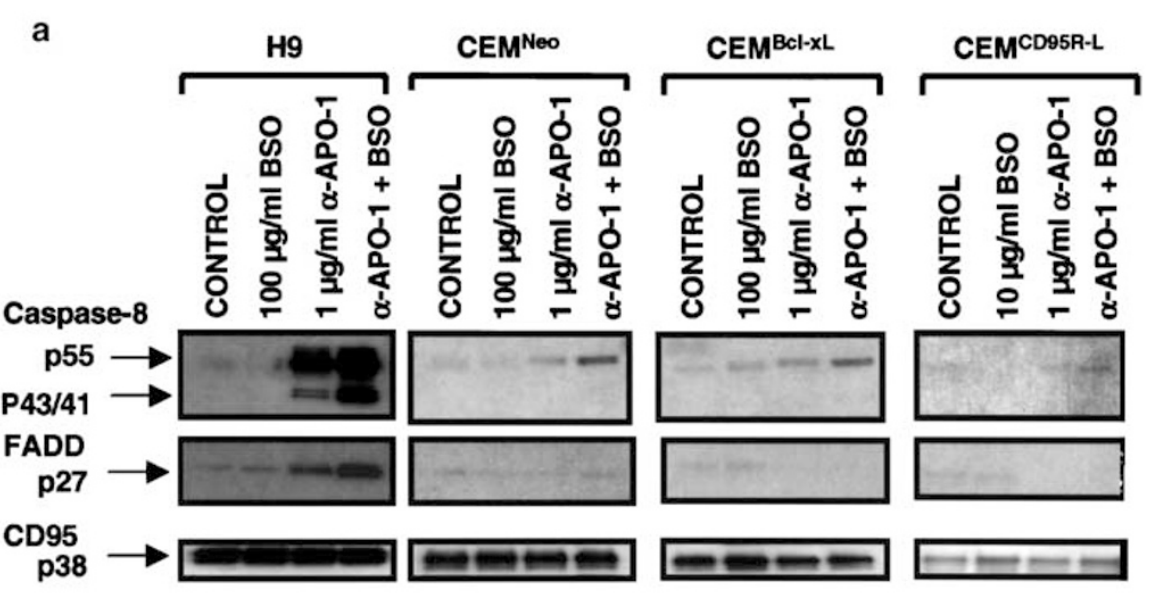

b
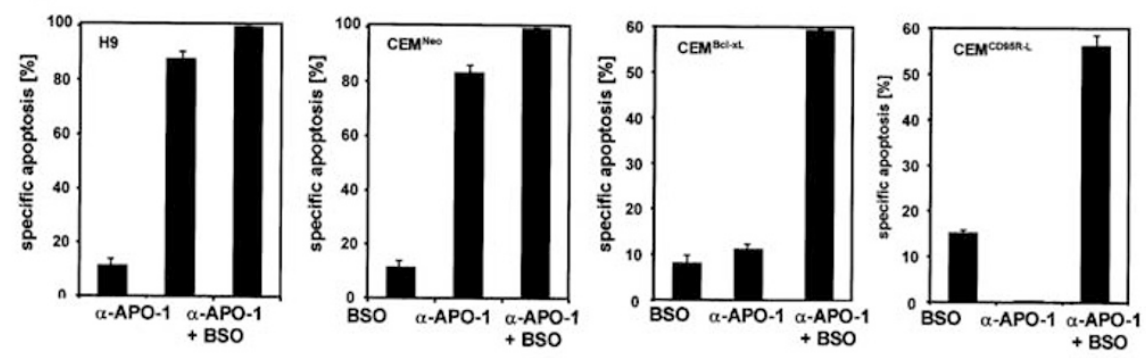

C
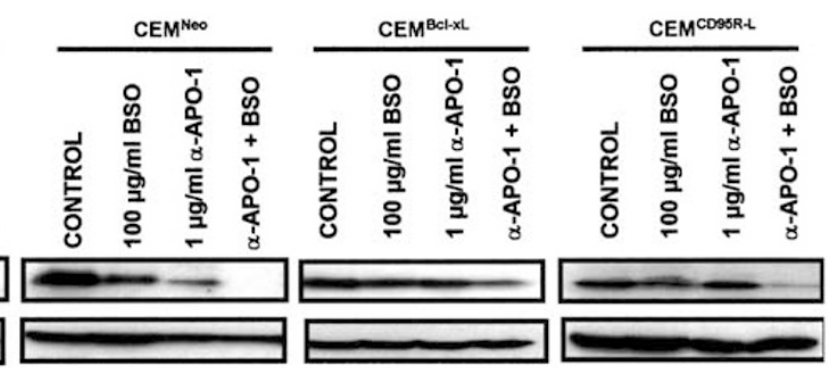

Figure 4 (a) BSO induced CD95 DISC formation in H9, CEM ${ }^{\text {Neo }}$, CD95-resistant (CEM ${ }^{\text {CD95R-L }}$ ), and in BCl- $\mathrm{X}_{\mathrm{L}}$ overexpressing leukemia cells (CEM ${ }^{\text {Bcl-xL }}$ ). H9, $\mathrm{CEM}^{\mathrm{Neo}}$,

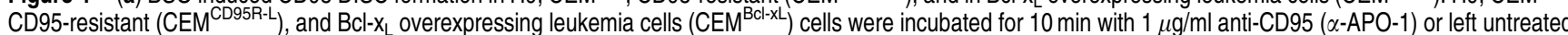
(CONTROL) or preincubated for $12 \mathrm{~h}$ with $100 \mu \mathrm{g} / \mathrm{ml}$ BSO (BSO) by addition of anti-APO-1 ( $\alpha$-APO-1 + BSO) at $37^{\circ} \mathrm{C}$. CD95 was immunoprecipitated. DISC preparation was performed. Detection of caspase-8 was performed using the mouse anti-caspase-8 monoclonal anitbody, which detects caspase-8 ( $\mathrm{p} 55$ ) and the cleavage intermediates p43/p41. FADD was detected using an mouse anti-FADD monoclonal antibody and CD95 was immunodetected by an rabbit anti-CD95 polyclonal antibody serving as a control for precipitation efficacy and protein loading. (b) BSO induced CD95-mediated apoptosis in H9, CEM ${ }^{\text {Neo }}$, CD95-resistant

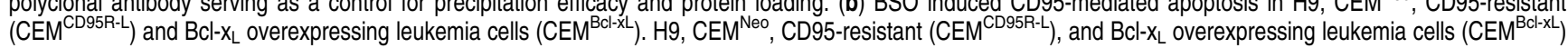
cells were incubated with $1 \mu \mathrm{g} / \mathrm{ml}$ anti-APO- $1\left(\alpha\right.$-APO-1) or preincubated for $12 \mathrm{~h}$ with $100 \mu \mathrm{g} / \mathrm{ml} \mathrm{BSO}$ (BSO) by addition of anti-APO-1 $(\alpha-\mathrm{APO}-1+\mathrm{BSO})$ at $37^{\circ} \mathrm{C}$. After $48 \mathrm{~h}$, the percentage of apoptotic cells was measured by FSC/SSC in leukemia cells. ${ }^{55}$ Data are given as mean of triplicates with an S.D. of less than $10 \%$. Similar results were obtained in three independent experiments. Percentage of specific cell death was calculated as described in Figure 1a. (c) BSO induced CD95-mediated Bid

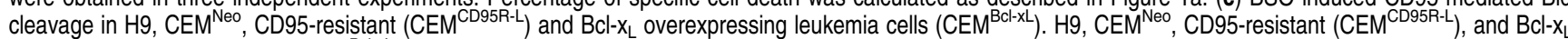
overexpressing leukemia cells (CEM ${ }^{\text {BCl-xL }}$ ) cells were incubated with $1 \mu \mathrm{g} / \mathrm{ml}$ anti-APO-1 $(\alpha$-APO-1) or left untreated (CONTROL) or preincubated for $12 \mathrm{~h}$ with $100 \mu \mathrm{g} / \mathrm{m}$ BSO (BSO) by addition of anti-APO-1 ( $\alpha$-APO- $1+\mathrm{BSO})$ at $37^{\circ} \mathrm{C}$. Western blot analysis for Bid was performed. Equal protein loading was controlled by beta-actin

induction of apoptosis was examined (Figure 4b). In type I cells, $\mathrm{H} 9$ cells, increased recruitment of FADD and caspase-8 was found after preincubation with BSO in addition to CD95 triggering (Figure 4a), indicating that an increased DISC formation was observed, which was associated with increased apoptosis induction (Figure 4b). This suggests that apoptosis induction and signaling is affected at the level of the
DISC by GSH in $\mathrm{H} 9$ cells. In type II cells, CEM ${ }^{\mathrm{Neo}}, \mathrm{CEM}^{\mathrm{CD} 95 \mathrm{R}-\mathrm{L}}$, and $\mathrm{CEM}^{\mathrm{Bcl}-\mathrm{xL}}$, exhibiting less CD95 on the surface in comparison to $\mathrm{H} 9$ cells, which do not form a DISC, recruitment of caspase-8 to the CD95 DISC was only found in BSO cotreated cells (Figure 4a). Only upon overexposure very little FADD or caspase-8 were detected in the DISC in parental sensitive CEM and CEM ${ }^{\mathrm{Neo}}$ cells (type II cells) in line with the 
established concept of type I and type II cells established with these cells. ${ }^{43,44}$ Thus, restoration of CD95 sensitivity by BSO in resistant cells does not affect DISC formation. Interestingly, increased Bid cleavage was found after preincubation with BSO, followed by CD95 triggering (Figure 4c), suggesting that Bid cleavage was associated with increased apoptosis induction (Figure 4b).

\section{Chemosensitivity of hybrids of apoptosis-resistant and -sensitive cells}

In order to examine the efficacy of GSH-mediated apoptosis resistance, PEG-mediated cell fusion studies were performed with the chemosensitive B-cell line, SKW6, and the CD95resistant $\mathrm{T}$-cell line $\mathrm{CEM}^{\mathrm{CD} 95 \mathrm{R}-\mathrm{L}}$ (Figure $5 \mathrm{a}$ ). Hybrids and nonfused cells, present in the same mixture, could be identified by staining for different surface markers, and were treated with different anticancer drugs or APO-1 (CD95) antibody (Figure 5b). Nonfused SKW6 cells remained sensitive and nonfused $C^{C E M}{ }^{C D 95 R-L}$ remained resistant to anticancer drugs or CD95. However, hybrids of a sensitive cell and a CD95-resistant cell were as resistant to different anticancer drugs or CD95 as CD95-resistant single cells (Figure 5b), indicating that resistance of CD95 was dominant in hybrids not only for doxorubicin but also for other anticancer drugs, which may induce apoptosis by different molecular mechanisms. In addition, hybrids of chemosensitive cells were as sensitive as the parental cell lines, indicating that the resistant phenotype is dominant (data not shown). Furthermore, caspase-3 activation was blocked (Figure $5 \mathrm{c}$ ) and disruption of mitochondrial membrane potential (Figure $5 \mathrm{~d}$ ) and hyperproduction of ROS from mitochondria were significantly reduced in hybrids (Figure $5 d$ ). Similar to single resistant cells, downregulation of GSH by BSO could reverse resistance in these hybrids (Figure $5 \mathrm{e}$ ).

We next studied whether $\mathrm{Bcl}-\mathrm{x}_{\mathrm{L}}$ overexpressing hybrids could also be modulated by BSO. Hybrids of SKW6 with Bcl- $x_{L}$ overexpressing cells $\left(\mathrm{CEM}^{\mathrm{Bcl}-\mathrm{xL}}\right)$ found to be resistant to different anticancer drugs or CD95 similar to $\mathrm{Bcl}-\mathrm{x}_{\mathrm{L}}$ overexpressing cells (Figure $5 f$ ) and resistance could again be overcome by BSO treatment (Figure $5 \mathrm{~g}$ ). These data demonstrate that CD95 resistance and anticancer drug resistance associated with $\mathrm{CD} 95$ resistance or $\mathrm{Bcl}-\mathrm{x}_{\mathrm{L}}$ overexpression can be 'transferred' to produce resistance in hybrids, which can be modulated by the intracellular GSH levels.

\section{Discussion}

Deficiencies in apoptosis pathways may lead to resistance towards chemotherapy. ${ }^{1,2,13,14}$ Here we report that resistance to apoptosis induced by both CD95 triggering or anticancer drugs, appears to depend on intracellular GSH levels which may affect apoptosis signaling in different compartments, at the level of the CD95 DISC or at the level of mitochondria, depending on different cell types (type I or type II cells).

Activation of caspases as effector molecules in response to death stimuli may be triggered by at least two different initiator compartments, the death receptor pathway or the mitochondrial pathway. ${ }^{1}$ Defects in these pathways may lead to apoptosis resistance. To study the mechanisms of resistance and crossresistance in apoptosis pathways, we generated CD95-resistant CEM cells by consecutive rounds of antiAPO-1 (anti-CD95) treatment. Concomitant with increased CD95 resistance, these cells also gradually developed drug resistance and defects in apoptosis pathways, indicating that prolonged acquisition of death receptor resistance may be associated with resistance to other death pathways.

ROS have been implicated in both the initiation and execution of apoptosis, modulating apoptosis resistance. ROS are physiological metabolites, which may be generated from mitochondria. When ROS are produced in excessive amounts, mitochondria, nucleic acids, proteins, and lipids are extensively modified by oxidation. ${ }^{59}$ To counteract the harmful consequence of ROS generation, mitochondria are equipped with MnSOD and redox cycle using reduced $\mathrm{GSH}$ and $\mathrm{GSH}$ peroxidase. ${ }^{59} \mathrm{GSH}$ is the most abundant intracellular thiol that functions in reduction of disulfid linkages of proteins and acts as an antioxidant. ${ }^{46-49}$ In addition, GSH is involved in modulation of induction of apoptosis and CD95 ligand by anticancer drugs in chemosensitive and anticancer drugresistant cells. ${ }^{15,50}$ We found that concomitant with development of CD95 resistance and anticancer drug cross-resistance intracellular GSH levels increased in resistant cells in comparison to parental sensitive cells. Downregulation of intracellular GSH levels by BSO, a specific inhibitor of glutathione synthesis, restored doxorubicin- as well as CD95-induced apoptosis and reversed deficient caspase activation and deficient mitochondrial activation (downregulation of mitochondrial membrane potential, hyperproduction of ROS and release of cytochrome $c$ from mitochondria) after doxorubicin treatment or CD95 triggering in CD95-resistant CEM cells. In addition, we found that also in Bcl- $x_{L}$ overexpressing CEM cells resistant to doxorubicin and CD95 downregulation of GSH by BSO reversed deficient activation of caspases and mitochondria by doxorubicin treatment or CD95 triggering. These data suggest that GSH affects apoptosis sensitivity at different levels.

Recently, CD95 DISC formation and activation of caspase8 at the DISC was found to depend on intracellular GSH levels and ROS generation in SKW6.4. ${ }^{51}$ In different cell types, apoptosis is initiated either by activation of large amounts of caspase-8 at the CD95 DISC followed by rapid cleavage of caspase-3 (type I cells, for example, SKW 6.4, H9) or the mitochondrial apoptosis pathway is the preferred route as a result of reduced CD95 DISC formation in those cells (type II, for example, Jurkat, CEM) and mitochondria may function as an amplifier, activating both caspase- 8 and $-3 .{ }^{43-45}$ In $\mathrm{H} 9$ cells (type I cells), we observed an increased CD95 DISC formation after downregulation of intracellular GSH levels by BSO associated with increased apoptosis induction, increased caspase- 8 activation followed by Bid cleavage, indicating that apoptosis signaling was affected downstream of the CD95 DISC in this cell type. However, in CD95-resistant CEM cells (type II cells) and in Bcl- $x_{\mathrm{L}}$ overexpressing CEM cells (type II cells) as well as in the parental sensitive CEM cells (type II cells), only a slight CD95 DISC formation after coincubation of anti-APO-1 with BSO was found, suggesting that GSH does 
a

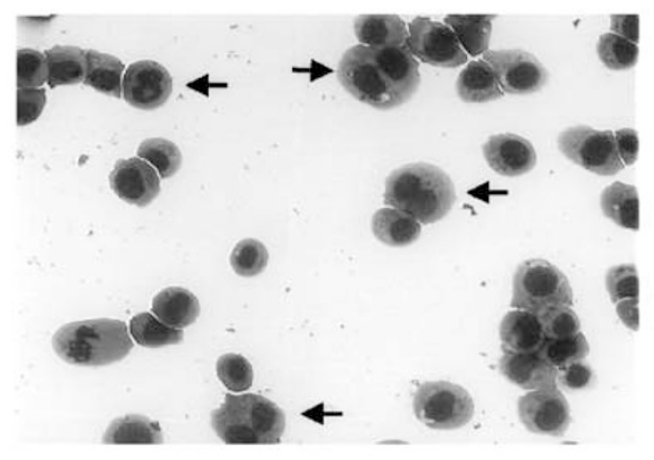

b
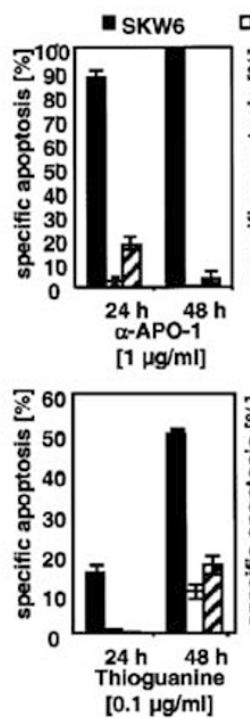
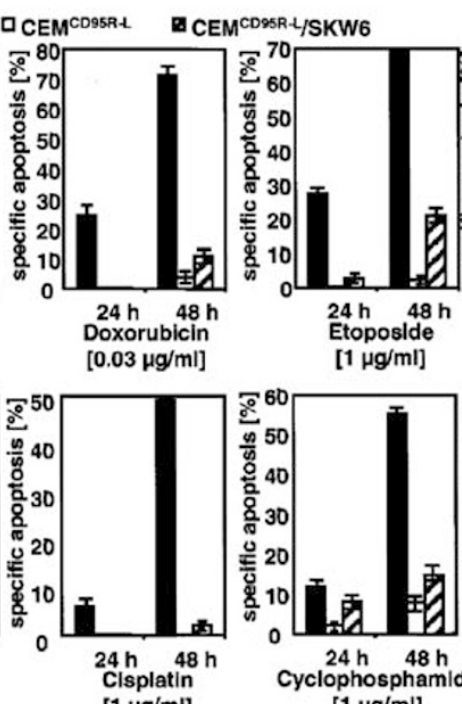

[1 $\mu \mathrm{g} / \mathrm{ml}]$

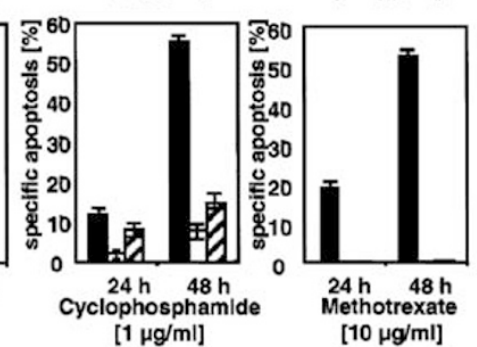

Figure 5 Anticancer drugs or CD95 induced apoptosis in sensitive cells (SKW6), in resistant cells (CEM ${ }^{C D 95 R-L}$ ), in Bcl- $x_{L}$ overexpressing cells (CEM ${ }^{B C l-x L}$ ), in hybrids

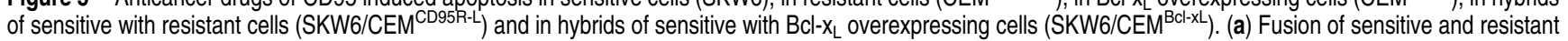
cells. Hybrids of sensitive and resistant cells exhibit two nucleii and hybrids are larger than nonfused cells. Arrows showed fused cells. (b) Anticancer drugs or CD95

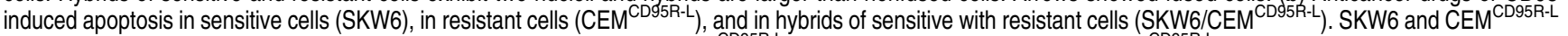
were fused with PEG. After $24 \mathrm{~h}$, mixture of cells SKW6 (black bars), CEM ${ }^{\mathrm{CD} 95 \mathrm{R}-\mathrm{L}}$ (white bars), and hybrids SKW6/CEM ${ }^{\text {CD95R-L }}$ (hachted bars) were incubated with different anticancer drugs or anti-APO-1 at concentrations and at time points as indicated. The percentage of apoptotic cells was measured by FSC/SSC with two fluorescence analyses gated on different cell population, fused SKW6/CEM ${ }^{\mathrm{CD} 95 \mathrm{R}-\mathrm{L}}$ cells exhibit CD7 and CD19, SKW6 cells exhibit CD19 and CEM ${ }^{\mathrm{CD} 95 R-\mathrm{L}}$ exhibit CD7 on surface. Percentage of specific cell death was calculated as described in Figure 1a. Data are given as mean of triplicates with an S.D. of less than 10\%. Similar results were obtained in three independent experiments. (c) CD95 induced activation of caspase-3 in sensitive cells (SKW6), in resistant cells (CEM ${ }^{\text {CD95R-L }}$ ), and in hybrids of sensitive with resistant cells (SKW6/CEM ${ }^{\text {CD95R-L }}$ ). SKW6 and CEM ${ }^{\mathrm{CD} 95 \mathrm{R}-\mathrm{L}}$ were fused with PEG. After $24 \mathrm{~h}$, mixture of cells SKW6, CEM ${ }^{\mathrm{CD} 95 \mathrm{R}-\mathrm{L}}$, and hybrids SKW6/ $\mathrm{CEM}^{\mathrm{CD} 95 \mathrm{R}-\mathrm{L}}$ were incubated with $0.1 \mu \mathrm{g} / \mathrm{ml}$ anti-APO-1 for $12 \mathrm{~h}$. Caspase-3 activation was measured with three fluorescence analyses gated on different cell population, fused SKW6/CEM ${ }^{\mathrm{CD} 95-\mathrm{L}}$ cells exhibit CD7 and CD19, SKW6 exhibit CD19 and CEM ${ }^{\mathrm{CD} 95 \mathrm{R}-\mathrm{L}}$ exhibit CD7 on surface. Similar results were obtained in three independent experiments. (d) Doxorubicin or CD95 induced downregulation of mitochondrial membrane potential $\left(\Delta \Psi_{\mathrm{m}}\right)$ in sensitive cells (SKW6), in resistant cells (CEM ${ }^{\mathrm{CD} 95 \mathrm{R}-\mathrm{L}}$ ) and in hybrids of sensitive with resistant cells (SKW6/CEM ${ }^{\mathrm{CD} 95 \mathrm{R}-\mathrm{L}}$ ). SKW6 and CEM ${ }^{\mathrm{CD} 95 \mathrm{R}-\mathrm{L}}$ were fused with PEG. After $24 \mathrm{~h}$ mixture of cells SKW6, CEM ${ }^{\mathrm{CD} 95 \mathrm{R}-\mathrm{L}}$, and hybrids SKW6/CEM ${ }^{\text {CD95R-L }}$ were incubated with $0.03 \mu \mathrm{g} / \mathrm{ml}$ doxorubicin (Doxo) or $0.1 \mu \mathrm{g} / \mathrm{ml}$ anti-APO-1 $(\alpha-A P O-1)$. After $12 \mathrm{~h}$, the frequency of cells with reduced $\Delta \Psi_{\mathrm{m}}$ [DiOC 6 $(3)^{\text {low }}$ ] was measured by gating on different cell populations, fused SKW6/CEM ${ }^{\mathrm{CD} 95 R-\mathrm{L}}$ cells exhibit CD7 and CD19, SKW6 exhibit CD19 and CEM ${ }^{\mathrm{CD} 95 \mathrm{R}-\mathrm{L}}$ exhibit CD7 on surface. Data are given as mean of triplicates with an S.D. of less than 10\%. Similar results were obtained in three independent experiments. (e) BSO reversed deficient doxorubicin- or CD95-induced apoptosis in resistant cells (CEM ${ }^{\mathrm{CD} 95 \mathrm{R}-\mathrm{L}}$ ) and in hybrids of sensitive with resistant cells (SKW6/CEM ${ }^{\mathrm{CD} 95 \mathrm{R}-\mathrm{L}}$ ). SKW6 and CEM ${ }^{\mathrm{CD} 95 \mathrm{R}-\mathrm{L}}$ were fused with PEG. After $24 \mathrm{~h}$ mixture of cells SKW6, CEM ${ }^{\text {CD95R-L }}$ (black bars), and hybrids SKW6/ CEM ${ }^{\text {CD95R-L }}$ (white bars) were incubated in 24 wells with $1 \mu \mathrm{g} / \mathrm{ml}$ antiAPO-1 ( $\alpha$-APO-1) or $0.03 \mu \mathrm{g} / \mathrm{ml}$ Doxorubicin (Doxo) or preincubated for $8 \mathrm{~h}$ with $100 \mu \mathrm{g} / \mathrm{ml}$ BSO (BSO) by addition of anti-APO-1 ( $\alpha$-APO-1 + BSO) or doxorubicin (Doxo + BSO) at $37^{\circ} \mathrm{C}$. After $24 \mathrm{~h}$ the percentage of apoptotic cells was measured by FSC/SSC with two fluorescence analyses gated on different cell populations, fused SKW6/CEM ${ }^{\text {CD95R-L }}$ cells exhibit CD7 and CD19, SKW6 exhibit CD19 and CEM ${ }^{\text {CD95R-L }}$ exhibit CD7 on surface. Percentage of specific cell death was calculated as described in Figure 1a. Data are given as mean of triplicates with an S.D. of less than $10 \%$. Similar results were obtained in three independent experiments. (f)

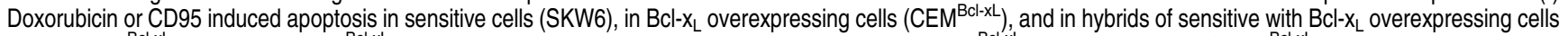

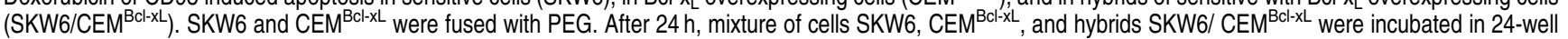
plates with $0.03 \mu \mathrm{g} / \mathrm{ml}$ doxorubicin (Doxo) or $0.1 \mu \mathrm{g} / \mathrm{ml}$ anti-APO-1 ( $\alpha$-APO-1) for $48 \mathrm{~h}$. The percentage of apoptotic cells was measured by FSC/SSC with two fluorescence analyses gated on different cell populations, fused SKW6/CEM ${ }^{B c 1-x L}$ cells exhibit CD7 and CD19, SKW6 exhibit CD19 and CEM ${ }^{B c 1-x L}$ exhibit CD7 on surface. Percentage of specific cell death was calculated as described in Figure 1a. Data are given as mean of triplicates with an S.D. of less than 10\%. Similar results were obtained in three independent experiments. (g) BSO reversed deficient doxorubicin- or CD95-induced apoptosis in Bcl- $\mathrm{X}_{\mathrm{L}}$ overexpressing cells (CEM ${ }^{\mathrm{BCl}-\mathrm{xL}}$ ) and in hybrids of sensitive with Bcl-XL overexpressing cells (SKW6/CEM ${ }^{\text {Bcl-xL }}$ ). SKW6 and CEM ${ }^{B c-x L}$ were fused with PEG. After $24 \mathrm{~h}$, mixture of cells SKW6, CEM ${ }^{B c-x L}$ (black bars), and hybrids SKW6/CEM ${ }^{\text {BCl-xL }}$ (white bars) were incubated in 24 wells with $1 \mu \mathrm{g} / \mathrm{ml}$ anti-APO ( $\alpha$-APO-1) or $0.03 \mu \mathrm{g} / \mathrm{ml}$ doxorubicin (Doxo) or preincubated for $8 \mathrm{~h}$ with $100 \mu \mathrm{g} / \mathrm{ml} \mathrm{BSO}$ (BSO) by addition of anti-APO-1 ( $\alpha$-APO-1 + BSO) or doxorubicin (Doxo + BSO) at $37^{\circ} \mathrm{C}$. After $24 \mathrm{~h}$ the percentage of apoptotic cells was measured by FSC/SSC with two fluorescence analyses gated on different cell populations, fused SKW6/CEM ${ }^{B C-x L}$ cells exhibit CD7 and CD19, SKW6 exhibit CD19 and $\mathrm{CEM}^{\mathrm{BCl}-\mathrm{xL}}$ exhibit CD7 on surface. Percentage of specific cell death was calculated as described in Figure 1a. Data are given as mean of triplicates with an S.D. of less than $10 \%$. Similar results were obtained in three independent experiments

not define the type I or type II phenotype. Interestingly, Bid cleavage was found after preincubation with BSO following CD95 treatment in CD95-resistant CEM cells and in $\mathrm{Bcl}-\mathrm{x}_{\mathrm{L}}$ overexpressing CEM cells, suggesting that Bid cleavage was associated with increased caspase-8 activation and increased apoptosis induction downstream of mitochondria. Since downregulation of GSH could reverse deficient activation of mitochondria in CD95-resistant CEM cells and in $\mathrm{Bcl}-\mathrm{x}_{\mathrm{L}}$ overexpressing CEM cells, GSH in type II cells appears to affect apoptosis signaling predominantly at the mitochondrial level.

Only few cell fusion studies have been performed addressing the mechanisms of drug resistance. ${ }^{60}$ Fusion of etoposide-sensitive cells with etoposide-resistant cells revealed a dominant resistance or an intermediate sensitivity of hybrids. ${ }^{58}$ We found that hybrids of CD95-resistant cells with chemosensitive cells produced the resistant response after anticancer drug treatment or CD95 triggering. Activation of 
C
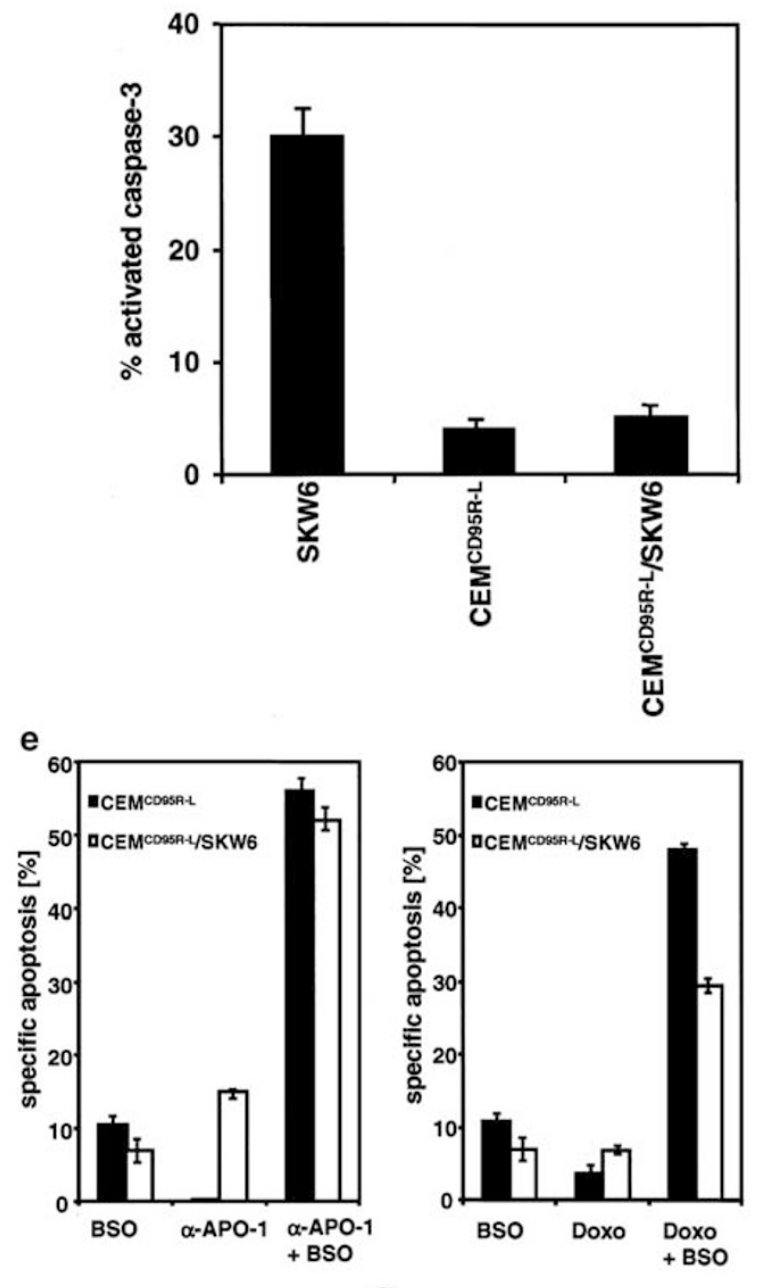

g

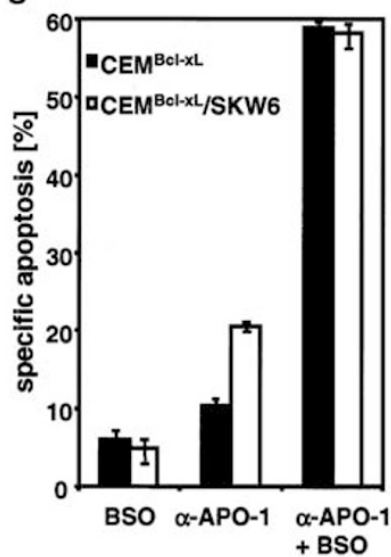

d
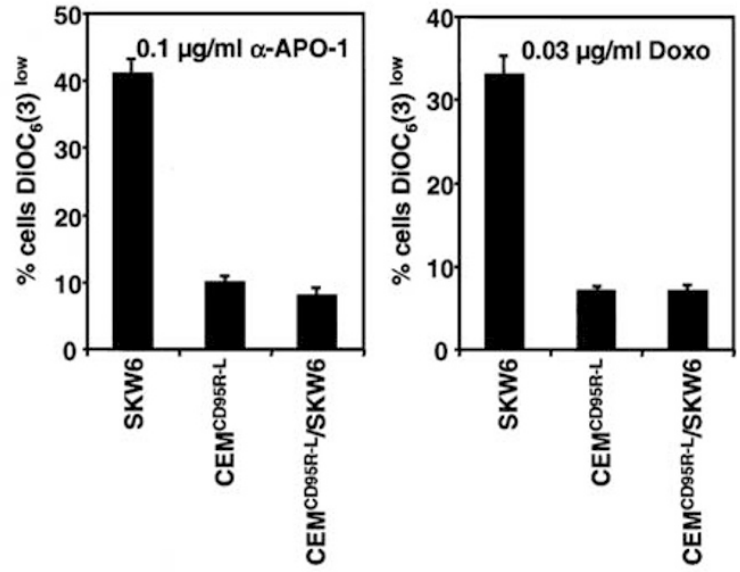

f
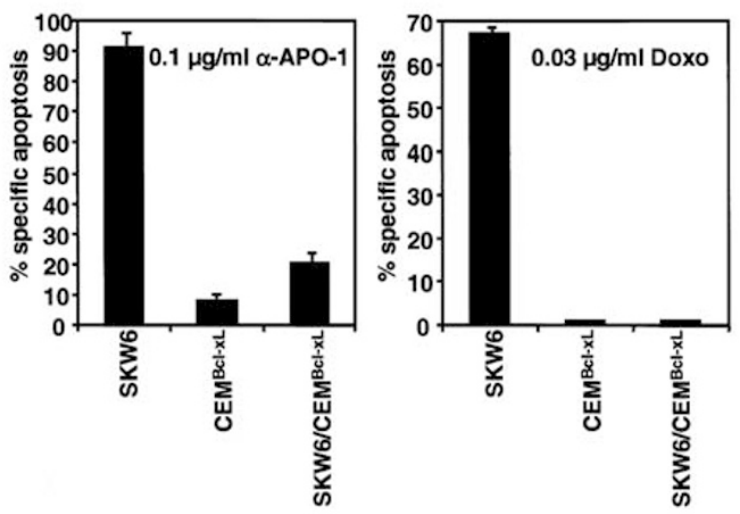

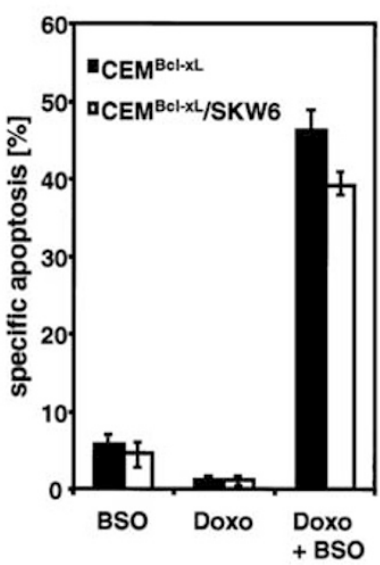

Figure 5 Continued

caspase-3 was deficient and downregulation of mitochondrial membrane potential and ROS production were reduced after CD95 triggering or doxorubicin treatment in hybrids of CD95resistant cells with sensitive cells in comparison to individual chemosensitive cells. This demonstrates that apoptosis resistance and defective activation of apoptosis pathways could be 'transferred' to sensitive cells in hybrids of an apoptosis-sensitive and -resistant cell. In contrast to CEM 
cells (type II cells), SKW6 cells (type I cells) form a DISC after triggering of CD95 and overexpression of Bcl- $x_{\mathrm{L}}$ does not block CD95-mediated apoptosis. ${ }^{43,44}$ In hybrids of $\mathrm{Bcl}-\mathrm{x}_{\mathrm{L}}$ overexpressing CEM (type II) and SKW6 (type I) cells, Bcl- $x_{\mathrm{L}}$ could block CD95- and anticancer drug-induced apoptosis, indicating that $\mathrm{Bcl}-\mathrm{x}_{\mathrm{L}}$-mediated resistance is dominant in hybrids also in type I cells. Interestingly, downregulation of intracellular GSH levels by BSO also reversed deficient anticancer drug- and CD95-induced apoptosis in Bcl- $\mathrm{x}_{\mathrm{L}}$ blocked type I/type II hybrids, indicating that GSH-mediated resistance of individual cells is also responsible for the 'transferred resistance' in hybrids.

Taken together, our data suggest that dominant CD95 resistance and anticancer drug resistance of CD95-resistant CEM cells or $\mathrm{BCl}-\mathrm{x}_{\mathrm{L}}$ overexpressing CEM cells associated with deficient activation of apoptosis pathways depend, at least in part, on intracellular GSH levels, which could affect apoptosis signaling in different compartments at the level of the death receptor or at the level of the mitochondria. Modulation of intracellular GSH levels may restore apoptosis sensitivity in previously resistant cells.

\section{Materials and Methods}

\section{Cell lines and culture conditions}

Leukemia $\mathrm{T}$ cells (CEM, CEM ${ }^{\text {CD95R-L }}, \mathrm{CEM}^{\mathrm{CD} 95 \mathrm{R}-4}, \mathrm{CEM}^{\mathrm{CD} 95 \mathrm{R}-5}$, $\mathrm{CEM}^{\mathrm{CD} 95 \mathrm{R}-8}, \mathrm{H9}$ ) and leukemia B cells (SKW6) were grown in RPMI 1640 (GIBCO BRL Eggenstein, Germany) containing 10\% fetal calf serum (Conco, Wiesbaden, Germany), 10 mM HEPES, pH 7.3 (Biochrom, Berlin, Germany), $100 \mathrm{U} / \mathrm{ml}$ penicillin (GIBCO), $100 \mu \mathrm{g} / \mathrm{ml}$ streptomycin (GIBCO), and $2 \mathrm{mM}$ L-glutamine (Biochrom). CEM ${ }^{\text {CD95R-L }}$, a variant of CEM resistant towards anti-APO- 1 (anti-CD95) up to $1 \mu \mathrm{g} / \mathrm{ml}$, was generated by continuous culture in anti-APO- 1 for more than 12 months ${ }^{12,13}$ (long-term CD95-resistant cells). To preserve the resistance of these cell line, $\mathrm{CEM}^{\mathrm{CD} 95 \mathrm{R}-\mathrm{L}}$ was treated every 2 weeks with anti-APO-1 (anti-CD95). For experiments, CEM ${ }^{\mathrm{CD} 95 \mathrm{R}-\mathrm{L}}$ cells were washed and cultured for 2 weeks in the absence of anti-APO-1 (anti-CD95). CEM ${ }^{\mathrm{CD} 95 \mathrm{R}-4}, \mathrm{CEM}^{\mathrm{CD95R}-5}$, and $\mathrm{CEM}^{\mathrm{CD} 95 \mathrm{R}-8}$ variants of CD95-resistant cell lines were not treated by continuous culture in anti-APO-1 for more than 12 months (long-term CD95-resistant cells), but were treated four times $\left(\mathrm{CEM}^{\mathrm{CD} 95 \mathrm{R}-4}\right)$, five times $\left(\mathrm{CEM}^{\mathrm{CD} 95 \mathrm{R}-5}\right)$ or eight times $\left(\mathrm{CEM}^{\mathrm{CD} 95 \mathrm{R}-8}\right.$ ) (short-term CD95resistant cells) with $1 \mu \mathrm{g} / \mathrm{ml}$ anti-APO-1. CEM ${ }^{\text {CD95R-4 }}$ and CEM ${ }^{\text {CD95R-5 }}$ were resistant towards anti-APO-1 (anti-CD95) up to $1 \mu \mathrm{g} / \mathrm{ml}$, but would not proliferate by continuous culture in anti-APO-1 (anti-CD95) for a long period of time. After eight rounds of treatment of CEM $\left(\mathrm{CEM}^{\mathrm{CD} 95 \mathrm{R}-8}\right)$ with anti-APO-1 (anti-CD95), CEM ${ }^{\text {CD95R-8 }}$ were resistant towards anti-APO-1 (anti-CD95) up to $1 \mu \mathrm{g} / \mathrm{ml}$ and can proliferate by continuous culture in antiAPO-1 (anti-CD95). These generated CD95-resistant (CEM ${ }^{\text {CD95R-8, }}$, short-term) cells were used for further experiments and for anticancer treatment. $\mathrm{CEM}^{\mathrm{NEO}}$ and $\mathrm{CEM}^{\mathrm{BCl}-\mathrm{xL}}$ were generated and cultured as described by Scaffidi et al. ${ }^{43}$ All cell lines were mycoplasma free.

\section{Drugs and reagents}

Doxorubicin (Doxo, Farmitalia, Milano, Italy), cytarabine (AraC) (Pfizer, Karlsruhe, Germany), cisplatin (Sigma Deisenhofen, Germany), cyclophosphamide (4-hydroperoxy-cyclophosphamide) (Baxter Oncology, Frankfurt, Germany), and vincristine (Bristol, Regensburg, Germany) were freshly dissolved in sterile distilled water, methotrexate (Whyet
Pharma, Münster, Germany) was freshly dissolved in steril $0.01 \mathrm{~N} \mathrm{NaOH}$, thioguanine (Deutsche Welcome, Burgwedel, Germany) and etoposide (Alexis, Grünberg, Germany) were freshly dissolved in sterile 0.05 vol\% DMSO, prior to each experiment to ensure constant quality of the preparations. All anticancer drugs were provided by the manufacturers as pure substances.

L-buthionine-( $S, R)$-sulfoximine (BSO) (Sigma, Deisenhofen, Germany) was freshly dissolved in sterile distilled water prior to each experiment to ensure constant quality of the preparations. Anti-APO-1 (anti-CD95) used for stimulation of cells and for the DISC were generated as described. ${ }^{54}$

\section{Induction of apoptosis}

For quantitative determination of apoptosis, cells were lysed in Nicoletti buffer $(0.1 \%$ sodium citrate plus $0.1 \%$ Triton $X-100$ (Sigma)) containing propidium iodide $(50 \mu \mathrm{g} / \mathrm{ml})$ as described. ${ }^{55}$ Propidium iodide-stained nuclei ${ }^{55}$ or forward scatter/side scatter (FSC/SSC) profile of cells ${ }^{56}$ were analyzed by flow cytometry (FACScan, Becton Dickinson, Heidelberg, Germany).

\section{Cytofluorometric analysis of mitochondrial transmembrane potential $\left(\Delta \Psi_{m}\right)$ and ROS generation}

To measure $\Delta \Psi_{\mathrm{m}}$ and ROS generation, cells $\left(5 \times 10^{5} / \mathrm{ml}\right)$ were incubated with 3,3'-dihexyloxacarbocyanine iodide $\left(\mathrm{DiOC}_{6}(3), 460 \mathrm{ng} / \mathrm{ml} ; \mathrm{FL}-1\right)$ (Moleculare Probes, Inc.,. Eugene, OR, USA) for $\Delta \Psi_{\mathrm{m}}$ and dihydroethidine (HE, $126 \mathrm{ng} / \mathrm{ml}$, FL-3) (Moleculare Probes) for ROS generation for $12 \mathrm{~min}$ at $37^{\circ} \mathrm{C}$ in the dark followed by analysis on a flow cytometer (FACScan).

\section{Analysis of reduced glutathione (GSH)}

Measurement of intracellular GSH (reduced glutathione, GSH) was done with the manufactory instructions of the Glutathione Assay Kit from Calbiochem (Calbiochem-Novabiochem Corporation, San Diego, CA, USA). The concentrations of GSH were calculated from a titration curve established using known concentrations of purified GSH and indicated in $\mathrm{nM}$ concentration (Sigma).

\section{Western blot analysis}

Proteins were extracted from cells lysed for $30 \mathrm{~min}$ at $4^{\circ} \mathrm{C}$ in PBS with $0.5 \%$ Triton X (Serva, Heidelberg, Germany) and $1 \mathrm{mM} \mathrm{PMSF} \mathrm{(Sigma),}$ followed by high-speed centrifugation. Protein concentration was assayed using bicinchoninic acid (Pierce, Rockford, USA). In all, $100 \mu \mathrm{g}$ protein per lane was separated by $10-20 \%$ SDS-PAGE and electroblotted to nitrocellulose (Amersham, Braunschweig, Germany). After blocking for $1 \mathrm{~h}$ in PBS supplemented with 5\% milk powder (Sigma) and 0.1\% Tween 20 (Sigma), immunodetection of PARP, caspase-3, active caspase-3, caspase-9, XIAP, Bcl- $\mathrm{x}_{\mathrm{L}}$, Bid, and $\beta$-actin was done using rabbit antiPARP polyclonal antibody $(1: 5000$, Enzyme Systems Products, Dublin, CA, USA), mouse anti-caspase- 3 monoclonal antibody ( $1: 500$, Transduction Laboratories), rabbit anti-active-caspase-3 polyclonal antibody (1:200, Chemicon International, Temecula, CA, USA), rabbit anticaspase-9 polyclonal antibody (1:5000, Transduction Laboratories), mouse anti-XIAP monoclonal antibody (anti-hILP, 1: 1000, Transduction Laboratories), rabbit anti-Bcl-x/L polyclonal antibody (1:1000, Santa Cruz, CA, USA), rabbit anti-Bid polyclonal antibody $(1: 1000, R \& D$ Systems 
$\mathrm{GmbH}$, Wiesbaden-Nordenstadt, Germany), or mouse anti- $\beta$-actin monoclonal antibody (Sigma) and peroxidase-conjugated goat anti-mouse $\lg \mathrm{G}$ or peroxidase-conjugated goat anti-rabbit IgG $(1: 5000$, Santa Cruz Biotechnology, Santa Cruz, CA, USA) followed by enhanced chemiluminescence system (ECL, Amersham Pharmacia).

\section{Cell fusion}

SKW6 and CEM ${ }^{\text {CD95R-L }}$ or SKW6 and CEM ${ }^{\text {Bcl-xL }}$ cells were washed with PBS twice. An equal number $\left(5 \times 10^{7}\right.$ cells $)$ of SKW6 and CEM ${ }^{\text {CD95R-L }}$ or SKW6 and $\mathrm{CEM}^{\mathrm{BCl}-\mathrm{xL}}$ cells were then mixed together and centrifuged, and all PBS were removed from the pellet. To fuse cells, $1.5 \mathrm{ml} \mathrm{PEG} 37^{\circ} \mathrm{C}$ (Polyethylene glycol 4000 from Merck, Hohenbrunn, Germany, preparing by solving $20 \mathrm{~g} \mathrm{PEG}$ in $28 \mathrm{ml}$ PBS containing $4.2 \mathrm{ml}$ DMSO in waterbath at $37^{\circ} \mathrm{C}$ ) was added slowly to the pellet. After $2 \mathrm{~min} 1.5 \mathrm{ml} \mathrm{PBS}$ was added at $37^{\circ} \mathrm{C}$. After $1 \mathrm{~min}, 10 \mathrm{ml} \mathrm{PBS}$ at $37^{\circ} \mathrm{C}$ was added slowly over $5 \mathrm{~min}$. Then $10 \mathrm{ml}$ PBS at $37^{\circ} \mathrm{C}$ was added quickly. Cells were centrifuged, supernatant was discarded, and the pellet was resuspended in $10 \mathrm{ml}$ RPMI 1640 medium with $10 \%$ FCS. Cell suspension $(10 \mathrm{ml})$ was returned to tissue culture flask with $90 \mathrm{ml} \mathrm{RPMI} 1640$ with $10 \% \mathrm{FCS}$ and allowed to recover for $24 \mathrm{~h}$ at $37^{\circ} \mathrm{C}$. After $24 \mathrm{~h}$, cells were used for experiments. The cell fusion resulted in variable recoveries of fused cells, with a range of 4 $8 \%$ fused products containing both SKW6 and CEM ${ }^{\mathrm{CD} 95 \mathrm{R}-\mathrm{L}}$ or SKW6 and $\mathrm{CEM}^{\mathrm{BCl}-\mathrm{xL}}$ cells. Cell fusion was verified by fluorescence cytometry.

\section{Analysis of SKW6/CEM ${ }^{\text {CD95R-L }}$ or SKW6/CEM ${ }^{\mathrm{Bcl}-\mathrm{XL}}$ hybrids}

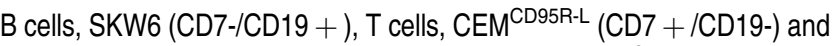
$\mathrm{CEM}^{\mathrm{BCl}-\mathrm{xL}}$ (CD7 + /CD19-) and hybrids, SKW6/CEM ${ }^{\mathrm{CD} 95 \mathrm{R}-\mathrm{L}}(\mathrm{CD} 7+1$ $\mathrm{CD} 19+)$, and SKW6/CEM ${ }^{\mathrm{BCl}-\mathrm{xL}}(\mathrm{CD} 7+/ \mathrm{CD} 19+)$ were identified by fluorescein isothiocyanate (FITC)-, phycoerythrin (PE) or PerCP-labeled monoclonal antibodies (anti-CD7 and -CD19; Becton Dickinson, BD, Heidelberg, Germany). Immunofluorescence analysis was performed on FACScan flowcytometer (Becton Dickinson).

\section{Caspase-3 activation detection}

Intracytoplasmic caspase-3 activation was detected using anti-caspase-3 antibody PE labeled (Pharmingen). Immunophenotypic groups were definded as follows: B cells, SKW6 (CD19 + /CD7-), T cells, CEM ${ }^{\text {CD95R-L }}$ $(C D 7+/ C D 19-)$, and hybrids SKW6/CEM ${ }^{\text {CD95R-L }}($ CD19 + /CD7 + ). Cells were permeabilized with IntraPrep ${ }^{\mathrm{TM}}$ Permeabilization Reagent (Immunotech, Marseilles, France) following manufacturer's instructions and stained for 45 min with different antibodies (CD7 FITC, anti-caspase-3 $\mathrm{PE}$ and CD19 PerCP, BD). After washing cells, immunofluorescence analysis was performed on FACScan flowcytometer (Becton Dickinson).

\section{Cytochrome $c$ release assay by FACScan analysis}

After fixing cell with PFA (4\%) at $4^{\circ} \mathrm{C}$ for 20 min, cells were washed, and permeabilized with $50 \mu \mathrm{l} 0.2 \%$. Saponin (in PBS) $+5 \mu \mathrm{g} \mathrm{MOPC-21}$ (Sigma) for $5 \mathrm{~min}$ by room temperature. After washing, cells were stained for $20 \mathrm{~min}$ at $4{ }^{\circ} \mathrm{C}$ with $20 \mu$ anti-cytochrome $c$ monoclonal antibody $(1: 20$, BD Pharmingen), cells were washed and were stained again with $20 \mu \mathrm{l}$ of a secondary antibody goat $F(a b)_{2}$ anti-mouse IgG FITC $(1: 20$, Southern Biotechology Associates, Inc.) for $20 \mathrm{~min}$ at $4^{\circ} \mathrm{C}$. After washing and fixing cells with $100 \mu$ IFA (4\%), immunfluorescence analysis was performed on FACScan flowcytometer (BD).

\section{Preparation of mitochondrial and cytosolic fraction}

Isolation of mitochondrial fraction and cytosolic fraction were done using the ApoAlert ${ }^{\mathbb{R}}$ Cell Fractionation Kit (BD Bioscience).

\section{Cytochrome $c$ release by Western blot analysis}

Isolation of mitochondrial fraction and cytosolic fraction was done using the ApoAlert ${ }^{\mathbb{R}}$ Cell Fractionation Kit (BD Bioscience). Western Blot analysis of cytochrome $c$ in mitochondrial fraction and cytosolic fraction were performed. In all, $25 \mu \mathrm{g}$ protein per lane was separated by $10-20 \%$ SDS-PAGE and electroblotted to nitrocellulose (Amersham). After blocking for $1 \mathrm{~h}$ in PBS supplemented with $5 \%$ milk powder (Sigma) and $0.1 \%$ Tween 20 (Sigma), immunodetection of cytochrome $c$ or Cox IV was done using mouse anti-cytochrome $c$ monoclonal antibody $(1: 1000, \mathrm{BD}$ Pharmingen) or mouse anti-OxPhos Complex IV subunit IV (Cox IV, $1: 200$, Molecular Probes) and peroxidase-conjugated goat anti-mouse $\lg$ (1:5000, Santa Cruz Biotechnology) followed by enhanced chemiluminescence system (ECL, Amersham Pharmacia). Mouse antiOxPhos Complex IV subunit IV, Cox IV, was used as control for purified mitochondrial fractionation.

\section{Immunoprecipitation of the CD95 DISC}

The formation of the CD95 DISC in H9 and CEM was studied by immunoprecipitation as described by Scaffidi et al. ${ }^{43} \mathrm{H} 9, \mathrm{CEM}, \mathrm{CEM}^{\mathrm{CD} 95 \mathrm{R}-}$ L, CEM ${ }^{\mathrm{NEO}}$, and $\mathrm{CEM}^{\mathrm{Bcl} \times \mathrm{L}}\left(2 \times 10^{5} / \mathrm{ml}\right)$ were incubated at $37^{\circ} \mathrm{C}$ with or without BSO. After $24 \mathrm{~h}$, the cells were maintained in $50 \mathrm{ml}$ tubes at number of $10^{7}$ cells $/ \mathrm{sample}$ and treated with $1 \mu \mathrm{g} / \mathrm{ml}$ anti-APO-1 monoclonal antibody $(\mathrm{mAb})$ for $10 \mathrm{~min}$ at $37^{\circ} \mathrm{C}$. After addition of $50 \mathrm{ml}$ of ice-cold PBS and short centrifugation $\left(460 \times g, 4^{\circ} \mathrm{C}, 5 \mathrm{~min}\right)$, the cell pellet was lysed (the lysis buffer was $1 \%$ Triton X-100, $150 \mathrm{mM} \mathrm{NaCl}$, $50 \mathrm{mM}$ Tris-Base (Sigma), pH 8 in addition per ml lysis buffer of $10 \mu \mathrm{l} \mathrm{mM}$ phenylmethylsulfonyl fluoride, $2 \mu \mathrm{l}$ DL-dithiothreitol and $1 \mu \mathrm{g}$ each leupeptin, aprotinin, chymostatin, and pepstatin A) for $15 \mathrm{~min}$ on ice. Severing as an unstimalted negative controls cells was lysed in lysis buffer before supplementation with anti-APO-1. After centrifugation of the lysates (15 min, $14000 \times \mathrm{g}, 4^{\circ} \mathrm{C}$ ) the CD95 DISC was precipitate for $12 \mathrm{~h}$ at $4^{\circ} \mathrm{C}$ from the supernatants with Pan mouse dynabeads IgG (Dynal Biotech, Hamburg, Germany). After immunoprecipitation the beads were washed first with buffer containing 1\% Igepal CA-630, $500 \mathrm{mM} \mathrm{NaCl}, 50 \mathrm{mM}$ Tris Base, pH 8 (Sigma) and second with buffer containing $25 \mathrm{mM}$ Tris Base (Sigma), pH 7.5 and then subsequently subjected to SDS-PAGE separation. Detection of caspase-8 was performed using the mouse anti-caspase-8 monoclonal anitbody $(1: 2000$, Alexis Deutschland, Günberg, Germany), which detectes caspase-8 (p55) and the cleavage intermediates p43/p41. FADD was detected using an mouse anti-FADD monoclonal antibody ( $1: 250$, Transduction Laboratories) and CD95 was immunodetected by an rabbit anti-CD95 polyclonal antibody $(1: 1000$, FAS, C-20, Santa Cruz Biotechnology) serving as a control for precipitation efficacy and protein loading. Peroxidase-conjugated goat anti-mouse IgG or peroxidase-conjugated goat anti-rabbit IgG (1:5000, Santa Cruz Biotechnology) was followed by enhanced chemiluminescence system (ECL, Amersham Pharmacia).

\section{Acknowledgements}

We thank Stefanie Rath for excellent technical assistance and Peter Krammer for providing the $\mathrm{Bcl}-\mathrm{xL}$ overexpressing CEM cells. This work 
was supported by EU grant QLG 1-CT-1999-00739 and Wilhelm SanderStiftung grant 2002.045.1.

\section{References}

1. Kaufmann SH and Earnshaw WC (2000) Induction of apoptosis by cancer therapy. Exp. Cell Res. 256: 42-49

2. Mesnder P, Budihardjo I and Kaufmann SH (1997) Chemotherapy-induced apoptosis. Adv. Pharmacol. 41: 461-499

3. Debatin KM (1996) Disturbances of the CD95 (APO-1/Fas) system in disorders of lymphohaematopoietic cells. Cell Death Differ. 3: 185-189

4. Itoh N, Yonehara S, Ishii A, Yonehara M, Mizushima S, Sameshima M, Hase A, Sato $N$ and Nagata $S$ (1991) The polypeptide encoded by the cDNA for human cell surface antigen Fas can mediate apoptosis. Cell 66: 233-243

5. Kischkel FC, Hellbardt S, Behrmann I, Gremer M, Pawlita M, Krammer PH and Peter M (1995) Cytotoxicity-dependent APO-1 (Fas/CD95)-associated proteins (CAP) form a death-inducing signalling complex (DISC) with the receptor. EMBO J 14: 5579-5588

6. Klas C, Debatin KM, Jonker RR and Krammer PH (1993) Activation interferes with the apoptotic pathway in mature human $\mathrm{T}$ cells. Int. Immunol. 5: $625-630$

7. Oehm A, Behrmann I, Falk W, Pawlita M, Maier G, Klas C, Li-Weber M, Richards S, Dhein J, Trauth B, Ponstingl H and Krammer PH (1992) Purification and molecular cloning of the APO-1 cell surface antigen, a member of the tumor necrosis factor/nerve growth factor receptor superfamily. J. Biol. Chem. 267: 10709-10715

8. Peter ME, Kischkel FC, Hellbrandt S, Chinnaiyan AM, Krammer PH and Dixit VM (1996) CD95 (APO-1/Fas)-associating signaling proteins. Cell Death Differ. 3: $161-170$

9. Dhein J, Walczak H, Bäumler C, Debatin KM and Krammer PH (1995) Autocrine $\mathrm{T}$ cell suicide mediated by APO-1 (Fas/CD95). Nature 373: 438-441

10. Suda T, Takahashi S, Golstein P and Nagata S (1993 Molecular cloning and expression of the Fas ligand, a novel member of the tumor necrosis factor family. Cell 75: 1169-1178

11. Tanaka M, Suda T, Takahashi T and Nagata S (1995) Expression of the functional soluble form of human Fas ligand in activated lymphocytes. EMBO J. 14: $1129-1135$

12. Friesen C, Herr I, Krammer PH and Debatin KM (1996) Involvement of the CD95 (APO-1/FAS) receptor/ligand system in drug-induced apoptosis in leukemia cells. Nat. Med. 2: 574-577

13. Friesen C, Fulda S and Debatin KM (1999) Drugs and the CD95 pathway. Leukemia 13: 1854-1858

14. Friesen C, Fulda S and Debatin KM (1997) Deficient activation of the CD95 (APO-1/Fas) system in drug-resistant cells. Leukemia 11: 1833-1841

15. Friesen C, Fulda S and Debatin KM (1999) Activation of the CD95 system by doxorubicin is modulated by the redox state in chemosensitive- and drugresistant tumor cells. Cell Death Differ. 6: 471-480

16. Fulda S, Sieverts H, Friesen C, Herr I and Debatin KM (1997) The CD95 (APO$1 / \mathrm{Fas}$ ) system mediates drug-induced apoptosis in neuroblastoma cells. Cancer Res. 57: 3823-3829

17. Fulda S, Los M, Friesen C and Debatin KM (1998) Chemosensitivity of solid tumor cells is associated with activation of the CD95 system. Int. J. Cancer 76: $105-114$

18. Fulda S, Scaffidi C, Pietsch T, Krammer PH, Peter ME and Debatin KM (1998) Activation of the CD95 (APO-1/Fas) pathway in drug- and $\gamma$-irradiation-induced apoptosis of brain tumor cells. Cell Death Differ. 5: 884-893

19. Muller M, Strand S, Hug H, Heinemann EM, Walczak H, Hofmann WJ, Stremmel W, Krammer PH and Galle PR (1997) Drug-induced apoptosis in hepatoma cells is mediated by the CD95 (APO-1/Fas) receptor/ligand system and involves activation of wild-type p53. J. Clin. Invest. 99: 403-413

20. Kasibatla S, Brunner T, Genestier L, Echeverri F, Mahboubi A and Green DR (1998) DNA damaging agents induce expression of FAS ligand and subsequent apoptosis in T lymphocytes via activation of NF- $\kappa$-B. Mol. Cell 1: 543-551
21. Rueffli AA, Smyth MJ and Johnstone RW (2000) HMBA induces activation of caspase-independent cell death pathway to overcome P-glycoproteinmediated multidrug resistance. Blood 95: 2378-2385

22. Eischen CM, Kottke TJ, Martins LM, Basi GS, Tung JS, Earnshaw WC, Leibson PJ and Kaufmann SH (1997) Comparison of apoptosis in wild-type and Fasresistant cells: chemotherapy-induced apoptosis is not dependent on Fas/Fas ligand interactions. Blood 90: 935-943

23. Villunger A, Egle A, Kos M, Hartmann BL, Geley S, Kofler R and Greil R (1997) Drug-induced apoptosis is associated with enhanced Fas (Apo-1/CD95) ligand expression but occurs independently of Fas (Apo-1/ CD95) signaling in human T-acute lymphatic leukemia cells. Cancer Res. 57: $3331-3334$

24. Wesselborg S, Engels IH, Rossmann E, Los M and Schulze-Osthoff K (1999) Anticancer drugs induce caspase-8/FLICE activation and apoptosis in the absence of CD95 receptor/ligand interaction. Blood 93: 3053-3063

25. McGahon AJ, Pereira Costa AP, Daly L and Cotter TG (1998) Chemotherapeutic drug-induced apoptosis in human leukaemic cells is independent of Fas (APO-1/CD95) receptor/ligand system. Br. J. Haematol. 101: 539-547

26. Fulda S, Susin SA, Kroemer G, Debatin and KM (1998) Molecular ordering of apoptosis induced by anticancer drugs in neuroblastoma cells. Cancer Res. 58: 4453-4460

27. Fulda S, Strauss G, Meyer E and Debatin KM (2000) Functional CD95 ligand and CD95 DISC in activation-induced cell death and doxorubicin-induced apoptosis in leukemic T cells. Blood 95: 301-308

28. Kroemer $G$ and de The $H$ (1999) Arsenic trioxid, a novel mitochondriotoxic anticancer agent? J. Natl. Cancer Inst. 91: 743-745

29. Stahnke K, Fulda S, Friesen C, Strauss G and Debatin K-M (2001) Activation of apoptosis pathways in peripheral blood lymphocytes by in vivo chemotherapy. Blood 98: 3066-3073

30. Li P, Nijhawan D, Budihardjo I, Srinivasula S, Ahmad M, Alnemri AS and Wang X (1997) Cytochrome $c$ and dATP-dependent formation of Apaf-1/caspase- 9 complex initiates an apoptotic protease cascade. Cell 91: 479-489

31. Zou H, Henzel WJ, Liu X, Lutschg A and Wang X (1997) Apaf-1, a human protein homologous to $C$. elegans CED-4, participates in cytochrome $c$ dependent activation of caspase-3. Cell 90: 405-413

32. Susin SA, Lorenzo HK, Zamzami N, Marzo I, Snow BE, Brothers GM, Mangion J, Jacotot E, Costantini P, Loeffler M, Larochette N, Goodlett DR, Aebersold R, Siderovski DP, Penninger JM and Kroemer G (1999) Molecular characterization of mitochondrial apoptosis-inducing factor. Nature 397: $441-446$

33. Lorenzo HK, Susin SA, Penninger J and Kroemer G (1999) Apoptosis inducing factor (AIF): a phylogenetically old, caspase-independent effector of cell death. Cell Death Differ. 6: 516-524

34. Susin SA, Lorenzo HK, Zamzami N, Marzo I, Brenner C, Larochette N, Prevost MC, Alzari PM and Kroemer G (1999) Mitochondrial release of caspase-2 and caspase-9 during the apoptic process. J. Exp. Med. 189: 381-394

35. Zou H, Li Y, Liu X and Wang X (1999) An Apaf-1-cytochrome $c$ multimeric complex is a functional apoptosome that activates procaspase-9. J. Biol. Chem. 274: 11549-11556

36. Srinivasula SM, Hedge R, Saleh A, Datta P, Shiozaki E, Chai J, Lee RA, Robbins PD, Fernandes-Alnemri T, Shi Y and Alnemri E (2001) A conserved XIAP-interaction in caspase-9 and Smac/DIABLO regulates caspase activity and apoptosis. Nature 410: 112-116

37. Deveraux Q L, Leo E, Stennicke HR, Welsh K, Salvesen G S and Reed J (1999) Cleavage of human inhibitors of apoptosis protein XIAP results in fragments with distinct specifities for caspases. EMBO J. 18: 5242-5251

38. Yang E and Korsmeyer SJ (1996) Molecular thanatopsis: a discourse in the Bcl-2 family and cell death. Blood 88: 386-401

39. Weller M, Winter S, Schmidt C, Esser P, Fontana A, Dichgans J and Groscurth P (1997) Topoisomerase I inhibitors for human malignang glioma: differential modulation of p53, p21, bax and Bcl-2 expression and of CD95-mediated apoptosis by camptothecin and beta lapachone. Int. J. Cancer 73: 707-714

40. Marchetti P, Castedo M, Susin SA, Zamzami N, Hirsch T, Macho A, Haeffner A, Hirsch F, Geuskens M and Kroemer G (1996) Mitochondrial permeability transition is a central coordinating event of apoptosis. J. Exp. Med. 184: $1155-1160$

41. Decaudin D, Geley S, Hirsch T, Castedo M, Marchetti P, Macho A, Kofler R and Kroemer $\mathrm{G}$ (1997) Bcl-2 and Bcl- $\mathrm{X}_{\mathrm{L}}$ antagonize the mitochondrial dysfunction 
preceding nuclear apoptosis induced by chemotherapeutic agents. Cancer Res. 57: 62-67

42. Kim CN, Wang X, Huang Y, Ibrado AM, Liu L, Fang G and Bhalla K (1997) Overexpression of Bcl-xL inhibits Ara C-induced mitochondrial loss of cytochrome $c$ and other perubations that activate the molecular cascade of apoptosis. Cancer Res. 57: 3115-3120

43. Scaffidi CA, Fulda S, Srinivasan A, Friesen C, Feng L, Tomaselli KJ, Debatin KM, Krammer PH and Peter ME (1998) Two CD95 (APO-1/Fas) signaling pathways. EMBO J. 17: 1675-1687

44. Fulda S, Meyer E, Friesen C, Susin SA, Kroemer E and Debatin KM (2001) Cell type specific involvement of death receptor and mitochondrial pathways in drug-induced apoptosis. Oncogene 20: 1063-1075

45. Slee EA, Keogh SA and Martin SJ (2000) Cleavage of BID during cytotoxic drug and UV radiation-induced apoptosis occurs downstream of the point of Bcl-2 action and is catalysedby caspase-3: a potential feedback loop for amplification of apoptosis-associated mitochondrial cytochrome $c$ release. Cell Death Differ. 7: 556-565

46. Cervantes A, Pinedo HM, Lankelma J and Schuurhuis GJ (1988) The role of oxygen-derived free radicals in the cytotoxicity of doxorubicin in multi-drug resistant and sensitive human ovarian cancer cells. Cancer Lett. 41: 169-177

47. Chiba T, Takahashi S, Sato N, Ishii S and Kikuchi K (1996) Fas-mediated apoptosis is modulated by intracellular glutathione in human T cells. Eur. J. Immunol. 26: 1164-1169

48. Dèas $\mathrm{O}$, Dumont $\mathrm{C}$, Mollereau B, Mètivier D, Pasquier C, Bernard-Pomier G, Hirsch F, Charpentier B and Senik A (1997) Thiol-mediated inhibition of Fas and $\mathrm{CD} 2$ apoptotic signaling in activated human peripheral $\mathrm{T}$ cells. Int. Immunol. 9: 117-125

49. Hedley D and Chow S (1994) Glutathione and cellular resistance to anti-cancer drugs. Methods Cell. Biol. 42: 31-44

50. Hug H, Strand S, Grambihler A, Galle J, Hack V, Stremmel W, Krammer PH and Galle PR (1997) Reactive oxygen intermediates are involved in the induction of CD95 ligand mRNA expression by cytostatic drugs in hepatoma cells. J. Biol. Chem. 272: 28191-28193
51. Hentze H., Schmitz I., Latta M, Krueger A, Krammer PH and Wendel A (2002) Glutathione dependence of caspase-8 activation at the death-inducing signaling complex. J. Biol. Chem. 277: 5588-5595

52. Sandstrom PA, Mannie MD and Buttke TM (1994) Inhibition of activationinduced death in T cells hybridomas by thiol antioxidants: oxidative stress as a mediator of apoptosis. J. Leuk. Biol. 55: 221-226

53. Doroshow JH and Davies KJ (1986) Redox cycling of anthracyclines by cardiac mitochondria. II. Formation of superoxide anion, hydrogen peroxide, and hydroxyl radical. J. Biol. Chem. 261: 3068-3074

54. Trauth BC, Klas C, Peters AMJ, Matzku S, Möller P, Falk W, Debatin K-M and Krammer PH (1989) Monoclonal antibody-mediated tumor regression by induction of apoptosis. Science 245: 301-305

55. Nicoletti I, Migliorati G, Pagliacci MC, Grignani F and Riccardi C (1991) A rapid and simple method for measuring thymocyte apoptosis by propidium iodide staining and flow cytometry. J. Immunol. Meth. 139: 271-279

56. Carbonari M, Cibati M, Cherchi M, Sbarigia D, Pesce AM, Dell'Ann L, Modica A and $M$ (1994) Detection and characterization of apoptotic peripheral blood lymphocytes in human immunodeficiency virus-infection and cancer chemotherapy by a novel flow immunocytometric method. Blood 83: 1268-1277

57. Muller C, Chatelut E, Gualano V, De Forni M, Huguet F, Attal M, Canal P and Laurent $G$ (1993) Cellular pharmacokinetics of doxorubicin in patients with chronic lymphocytic leukemia: comparison of bolus administration and continuous infusion. Cancer Chemother. Pharmacol. 32: 379-384

58. Celli A, Que FG, Gores GJ and LaRusso NF (1998) Glutathione depletion is associated with decreased Bcl-2 expression and increased apoptosis in cholangiocytes. Am. J. Physiol. 275: 749-757

59. Richter C, Gogvadze V, Laffranchi R, Schlapbach R, Schweizer M, Suter M, Walter P and Yaffee M (1995) Oxidants in mitochondria: from physiological diseases. Biochim. Biophys. Acta 1271: 67-74

60. Luo C, Johnston PJ, MacPhail SH, Banath JP, Oloumi A and Olive PL (1998) Cell fusion studies to examine the mechanism for etoposide resistance in Chinese hamster V79 spheroids. Exp. Cell Res. 243: 282-289 